\title{
各種歯髄疾患における神経線維の動態に関する研究
}

\author{
九州菌科大学口腔病理学講座（指導：上野正康教授） \\ 安藤信義 \\ 昭和59年11月22日受付
}

\section{Change of Nerve Fibers in Various Pulp Diseases}

\author{
Nobuyoshi Andoh \\ Department of Oral Pathology (Director : Prof. Masayasu Ueno) \\ Kyushu Dental College, Kitakyushu, Japan
}

In order to study the change of pulp nerve fibers in various pulp diseases, continuous sections of 227 extracted human teeth were made, stained by nerve staining method, and observed. The results were as follows:

1. In pulp hyperemia, those in the early stages did not show marked difference in nerve fibers. However, in the case with continuous hyperemia, findings of slight swelling, hypochromatosis and beading were observed.

2. In acute serous pulpitis, findings of slight swelling, hypochromatosis, and meandering of the nerve fibers in the inflammation focus and around the focus were observed. These changes however were observed mostly in thick nerve fibers; most thin nerve fibers showed healthy findings.

3. In acute suppurative pulpitis in which inflammation was limited to a part, most of the nerve fibers in the inflammatory tissue surrounding the localized suppurative focus were degenerated. However, healthy nerve fibers were observed in thin nerve fibers. When suppurative inflammation extended to the whole pulp, most nerve fibers showed degenerative findings.

4. In the case of acute gangrenous pulpitis, whole nerve fibers were degenerated markedly or in decomposition process.

5. In the ulcerative membrane of chronic ulcerative pulpitis and in the abscess membrane of chronic closed pulpitis, reticular distribution of remarkably minute nerve fibers was observed.

6. A considerable number of regenerated nerve fibers were observed in pulp polyp and some with free nerve endings extending into the leucocyte layer in the outermost surface were seen.

7. No marked changes were seen in the nerve fibers distributed in the odontoblastic layer which showed vacuolar degeneration.

8. Most of the nerve fibers in the calcareously degenerated portion underwent swelling, laceration, and granular decomposition. A number of them were about to disappear. 
9. In reticular atrophy, almost no changes were observed in the early stages. However, degeneration of nerve fibers progressed as atrophy progressed. In the case where atrophy extended to the whole pulp, most nerve fibers showed marked degenerative findings.

10. The foregoing findings indicate that nerve fibers in dental pulp show strong resistance against destructive changes of various pulp diseases and that they survive considerably longer than the surrounding tissues.

\section{Key words: Extracted teeth/Various pulp diseases/Nerve staining method/Nerve fibers in dental pulp}

\section{緒言}

歯䯣内神経線維に関する研究報告は，古くから数多く の研究者達により行われてきている.

歯髄内神経線維の走行および分布に関するものには， Wassermann (1939) ${ }^{11}$, 可児 $(1937)^{2)}$, 寺坂 (1939) ${ }^{3)}$, Bernick $(1948)^{4)}$, Powers $(1952)^{5)}$, Philipp $(1955)^{6)}$ ，高木弓 $(1973)^{\prime \prime}$, Itoh $(1976)^{81}$ ，伊東ら $\left.(1978)^{9}\right)^{\prime}$ など，数多くの報告例がみられ，著者の教室 でも，北村ら $(1958)^{101}$ ，上野ら $(1958 ， 1960)^{11} 1^{121}$ ，

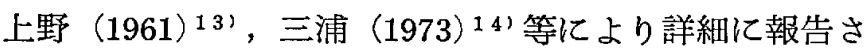
れている。

また，てれら歯蹎内神経線維の数およびその径につい

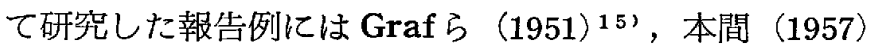
16), 内䓢ら (1958) ${ }^{17)}$, 内田 (1959) ${ }^{18)}$, 三好 (1966) 19), 三浦 $(1973)^{14}$ ) 等があり, 乳菌の分布状態を検索 したものには木村 $(1971)^{20}$ 等の報告がみられる.

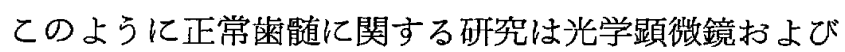
電子顕微鏡学的に, 詳細にわたり研究され, そのメカ二 ズムが明らかになるのも近い将来のととであろうと思わ れる。

しかしながら，てれら正常歯髄における研究に比較し て, 各種疾患時における歯髄内神経線維の動態について 検索した報告例は比較的少なく，岡部 $(1937 ， 1940)^{21}$, 22)，内田 (1959) 18)，Plačková (1966) ${ }^{23) ， M u l l a n e y ~}$ 弓 $(1970)^{24)}$, Martinelli ら $(1970)^{25)}$, Bernick $(1972)^{26)}$, 三浦 $(1973)^{141}$, Almeida 弓 $(1973)^{271}$, Torneck $(1974)^{281}$, England 弓 $(1974)^{291}$ 等は 菌髄 疾患時の歯㵦内神経線維について，可児ら $(1936)^{301}$ ，

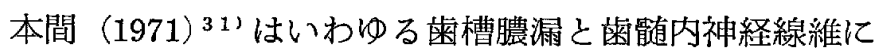
ついて, また中村 $\left.(1940)^{32}{ }^{2}\right)$ は歯髄内神経線維の死後変 化についてそれぞれ研究報告しているが，断片的なもの が多く，まだ充分とはいえないようである。
そてで著者は菌髄疾患時，すなわち，循環障害，歯髄 炎症および退行性病変にお污る歯牙内神経線維の動態を 詳細に追求し，また先人の知見を補遗すべく227本の抜去 歯牙を用いて観察し，若干の知見を得たので報告する。

\section{研究材料および方法}

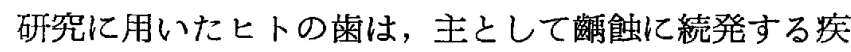
患により抜去されたもので，年令，性別，部位の明らか なものを用いた。

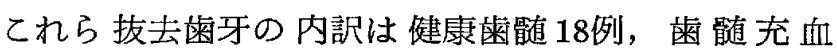
44例, 急性漿液性歯髄炎25例, 急性化膿性歯髄炎33例,

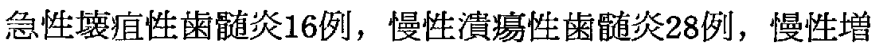
殖性菌䯙炎 7 例，慢性閉銧性菌䯣炎 9 例，石戻変性 10 例

(うち硝子様変性と混在して認められるもの3 例を含 む), 空胞変性 8 例, 網樣萎縮 29 例で, 総数 227 例であ る。

抜去後, 雨牙を直ちに神経染色用固定液に投入し，約 30 日間固定後, 蟻酸とクエン酸ナトリウムの等量混合液 にて眖灰した。

通法に従い，パラフィン包埋し，煩舌的に $10 \mu \mathrm{m}$ の連 続切片標本を作製し, Haematoxylin-Eosin 重染色お よび Ungewitter の尿素・硝酸銀法の Powers 変法を さらに改良した本学口腔病理学教室独自の方法を用い て, 神経染色を行い, 鏡見観察した。

\section{観 察 所 見}

\section{I ．健康歯髄 (18例)}

一般に根尖孔より歯牙内に進入する神経線維は，ほと んどは有髄線維で, 極く少数の無䯑道線維を容れている一 個の神経大束が血管と並行して崡葡内に進入している。 ての神経大束は根管中央部をほほ直線的に進むが，ての 大東から岐れて横走あるいは斜走して象牙芽細胞首まで 達する神経線維は非常に少なく一根餚において数本を数 
えるのみである、神経大束が歯頸部もしくは冠粗入口附 近に至ると, 主として歯髄の周辺部すなわち Weil 層下 を硬組織に平行して冠賄に向うが，冠髄中央部を指して 上昇する神経束も相当みられ，乙れらは血管の走行とほ ぼ一致している。

複根歯の場合は単根荬に比して幾分走向が複雑化して くる.

歯冠部に達した線維束は多数に分岐して扇状に㹡が り，冠揈周辺部の神経束はWeil の細胞希薄層下部にあ って,いわゆる Raschkow の神経㙚を形成している．乙 の神経叢より鋭角的に多数の細い分岐楾維を出して無䯣
終末を象牙芽細胞層下, 層内あるいは幼若象牙質中に送 っている.また，冠咀中央に分布する神経線維は周辺部 に比較して希薄であるが，血管の走向と密接不離の関係 を有し大小の血管に線維束が絿絡して走っている（写真 $1 \sim 7$ ).

II . 歯䰰充血 (44例)

歯檤充血とは血管内の血液量が過度に増加することに より，血管が拡張した状態で，乙れが漸次雨髄全体に波 及してゆき, 長くこの状態が続くと, 血管内より液性成 分の滲出がおこり，歯髄組織の水腫をひきおてず.

したがって，歯鹃道内の神経線維も，歯娟充血の時期，

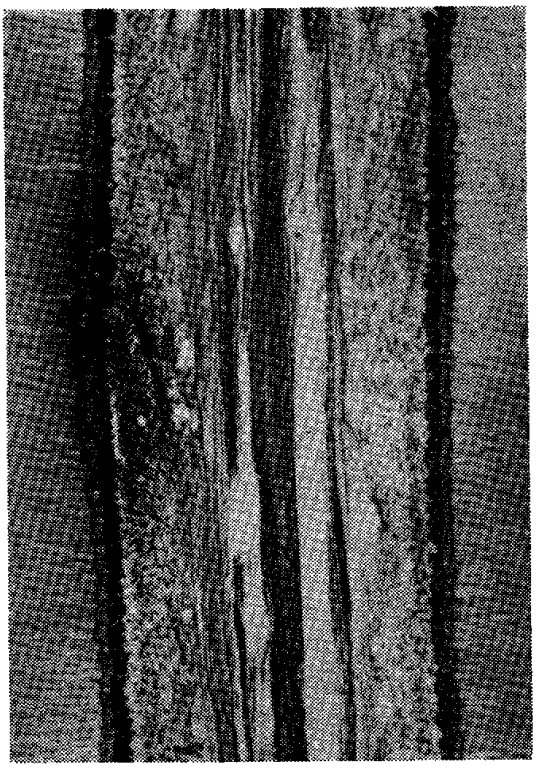

写真 1

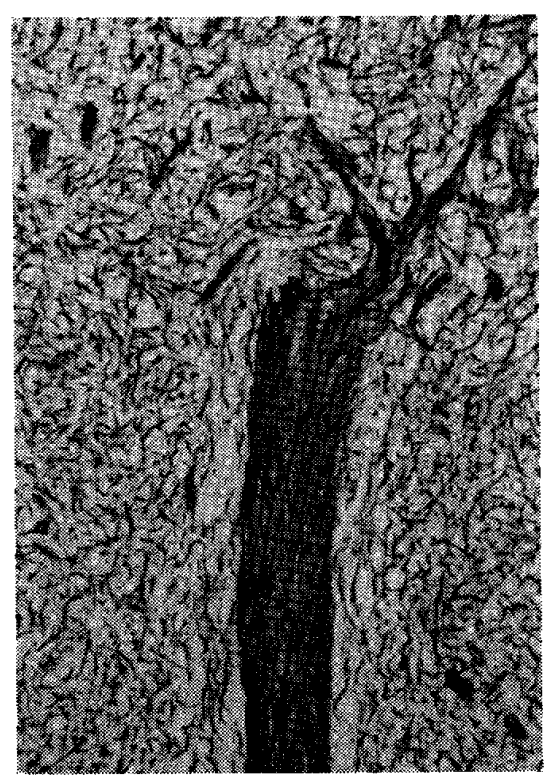

写 真 4

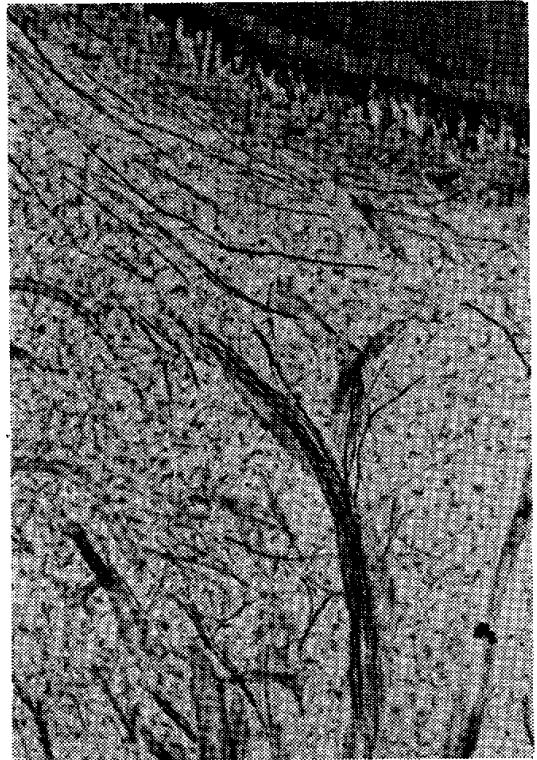

写 真 2

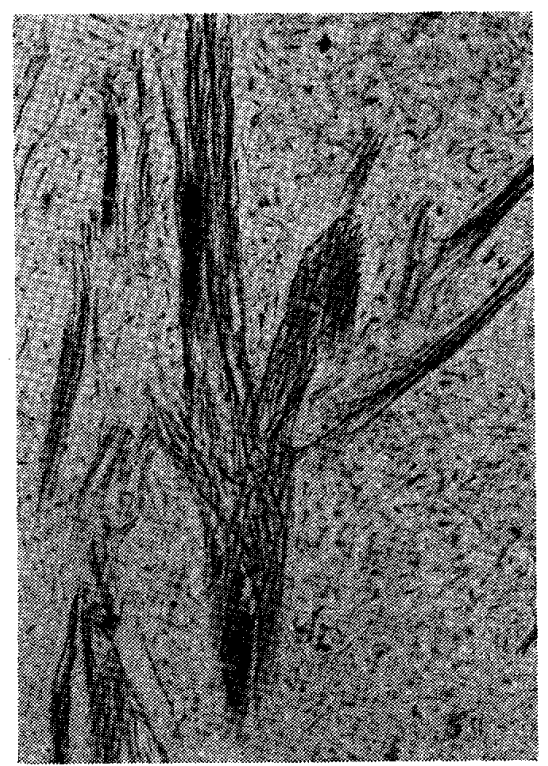

写 真 5

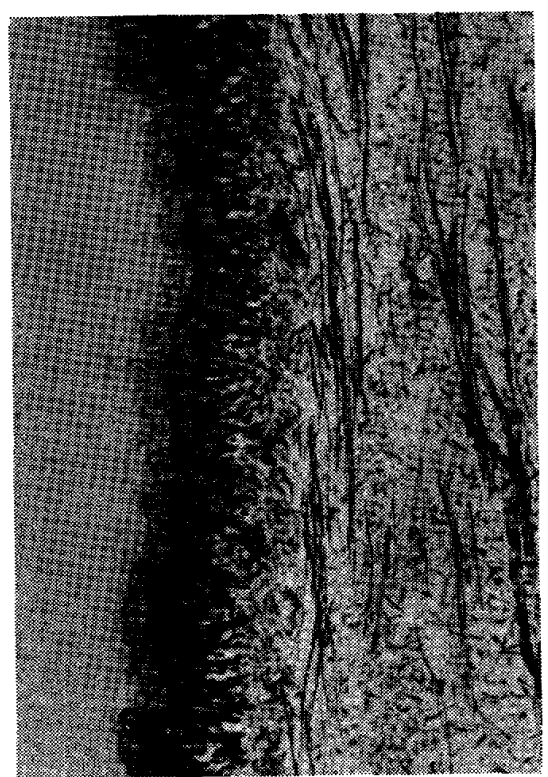

写 真 3

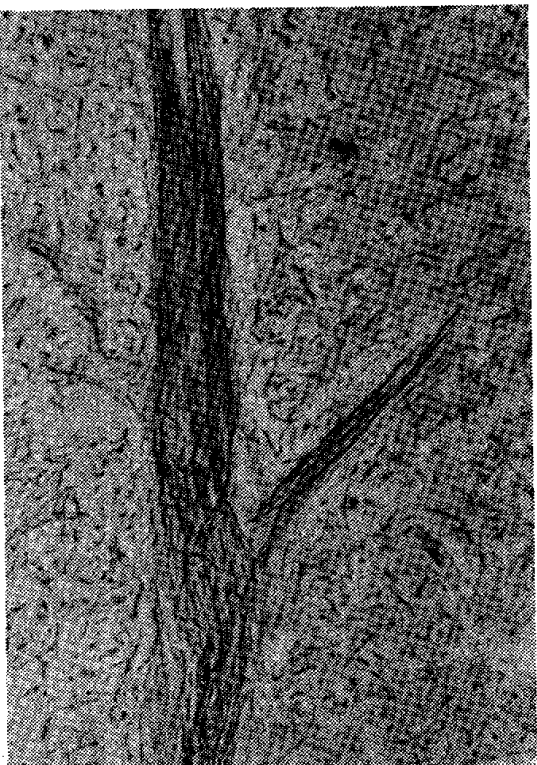

写 真 6 


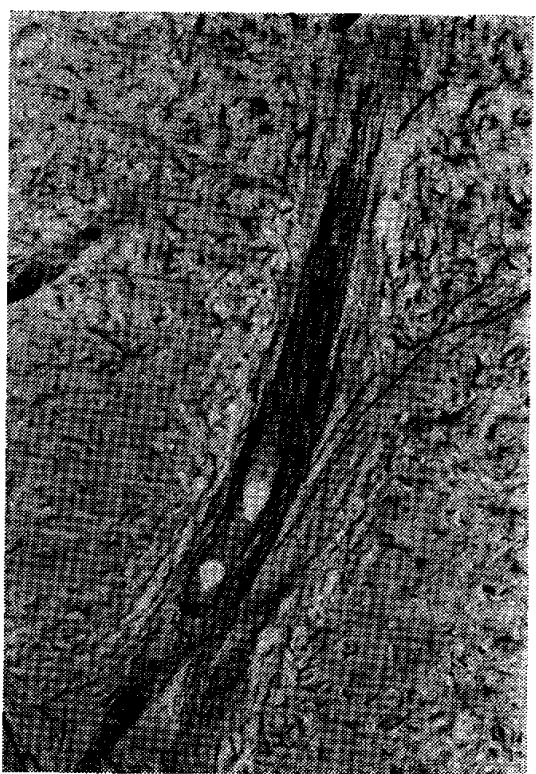

写 真 7

またはその程度により異なった所見を呈している。すな わち, 鬴充血が比較的初期のものでは, 神経線維には 全く著変は認められなかったが, 充血が永続している症 例では, 歯髄組織内に水腫が惹起されているため，ての 水腫内を走行する神経線維は膨化，染色性の低下，ある いは部分的狭窄と膨大による念珠状変化をおてすものが みられ，また走行が不規則になった神経線維も認められ た。

しかしながら，てれらの変性に陥った神経線維は，そ の多くは径の太いもので, 径の細い神経線維には著変は 認められなかった（写真 8 〜 15 ).
III. 炎症性疾患

1）急性娄能道炎

a . 急性漿液性霜髄炎 (25例)

急性漿液性歯䯣炎は炎症としては最も初期の段階であ り，炎症が歯骾の一部に限局する一部性漿液性雪髄炎と 歯葡全体におよぶ全部性漿液性歯髄炎とに区別される。

今回, 著者が観察したのは, 一部性歯髄炎23例, 全部 性菌髄炎 2 例の計25例である。

急性一部性漿液性雨髄炎に抢ける神経線維は，炎症巣 およびその周囲を走行するものは，膨化，染色性の低下 および蛇行などの変性に陌った所見が認められたが，乙 れらの変性に陥った神経線維はその径の大きいものがほ とんどで, 径の小さなもの, すなわち, 細い神経線維は その大多数が健全な所見を呈している.

これらの部位以外の歯髄内を走行する神経線維には著 変は認められなかった。

次に，全部性歯髄炎の症例では，炎症巣内を走行する 神経線維は膨化, 蛇行, 染色性の低下および顆粒化をお こすものがみられた．また，乙のような変性に陷った神 経線維とともに増殖する Schwann 細胞を含む神経束が みられた。しかしながら，てのような症例においても， てれらの変性に陥った神経とともに，未だ健全な細い神 経線維が多数認められた（写真16〜23）.

b ．急性化膿性歯髄炎 (33例)

急性化膿性歯髄炎は嶈液性歯髄炎が化膿性炎症に移行

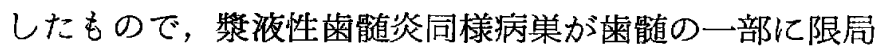
する一部性と歯䯣全体におよぶ全部性とに区別される.

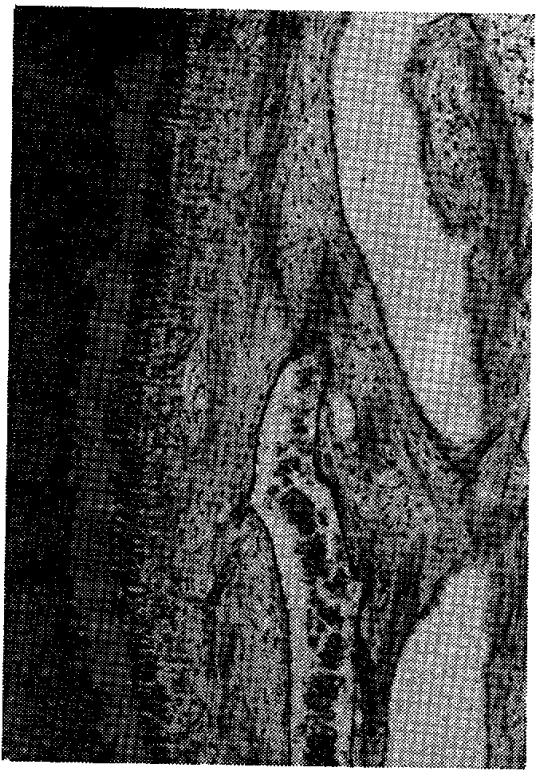

写 真 8

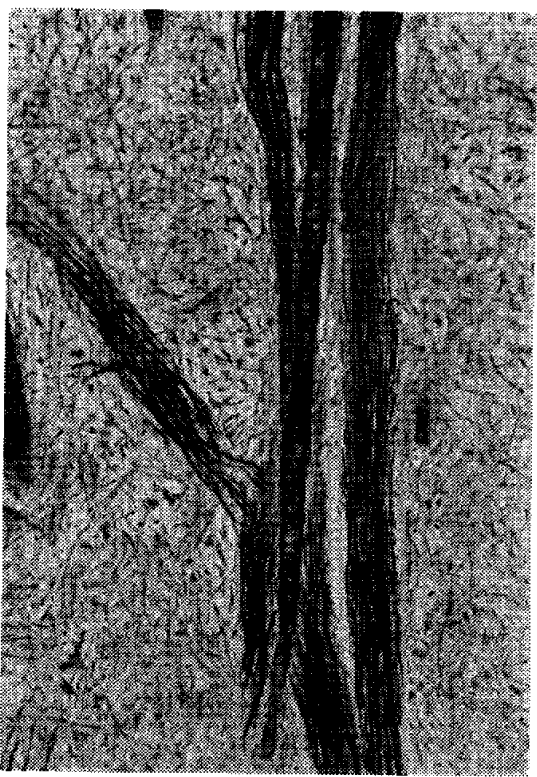

写 真 9

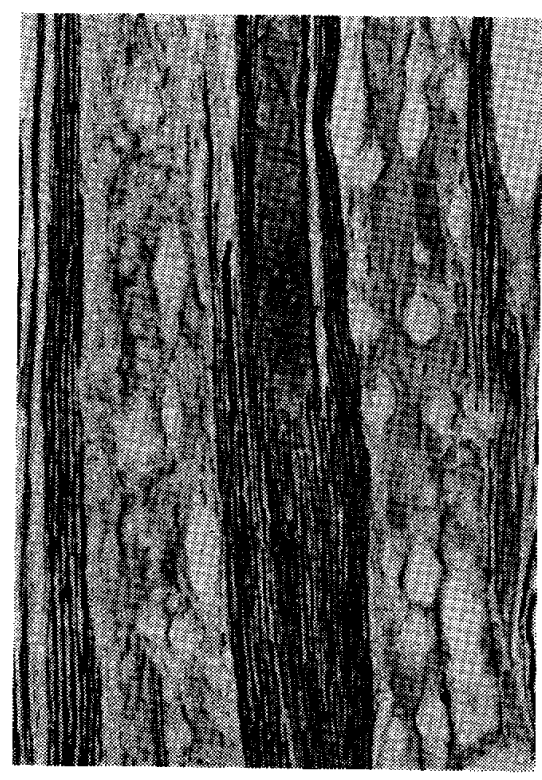

当. 真 10 


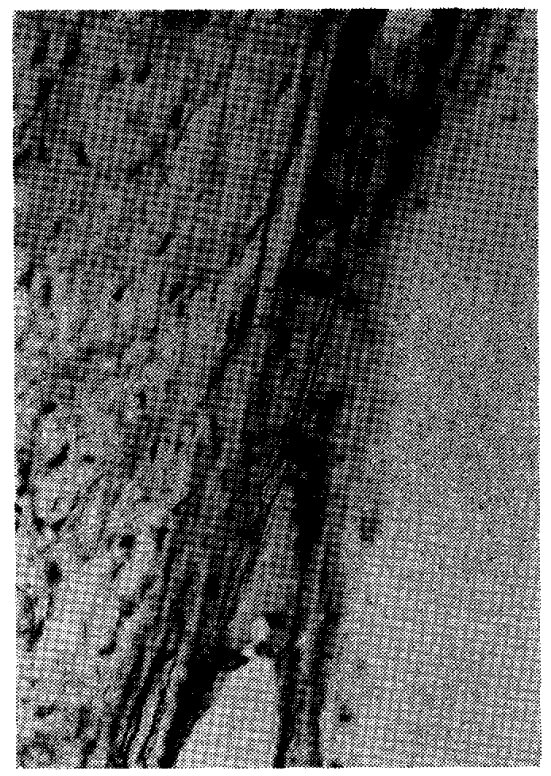

写 真 11

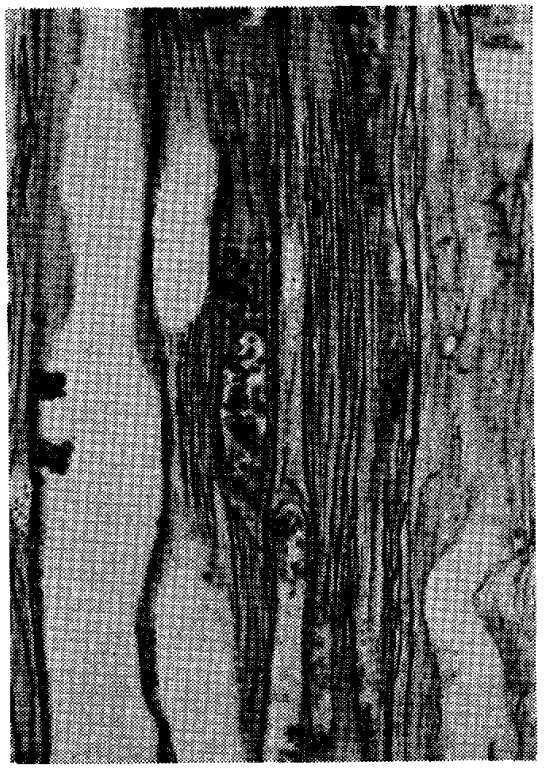

写 真 12

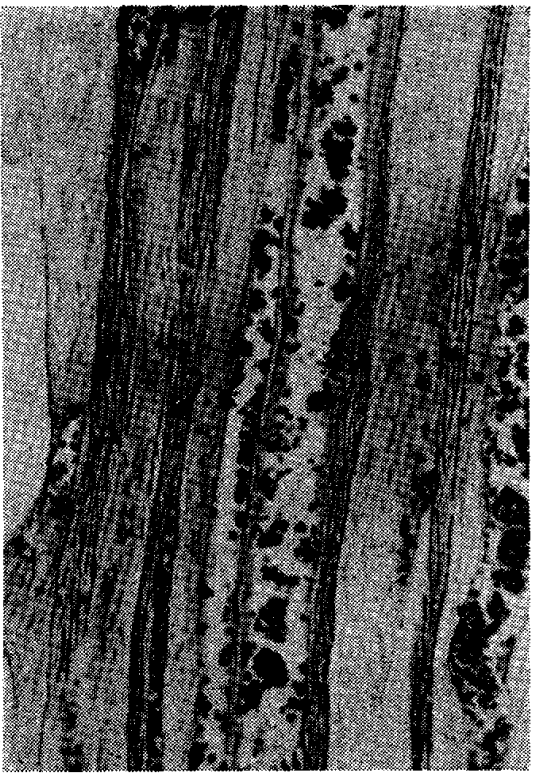

写 真 13

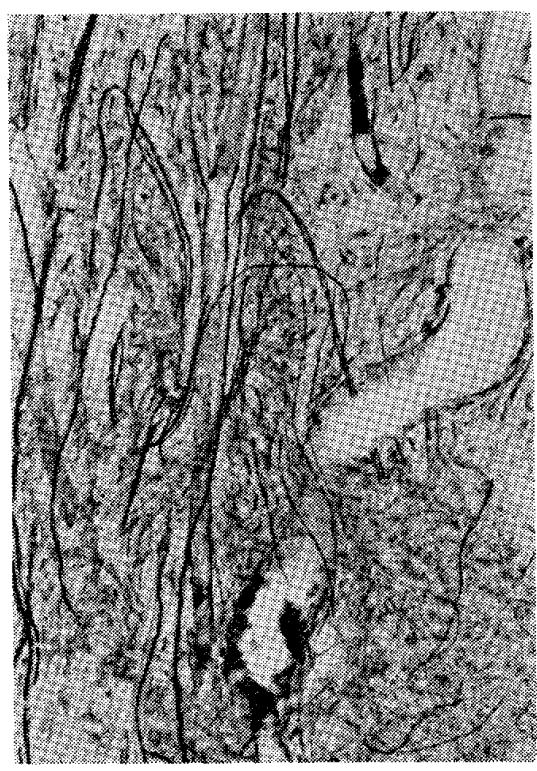

写 真 14

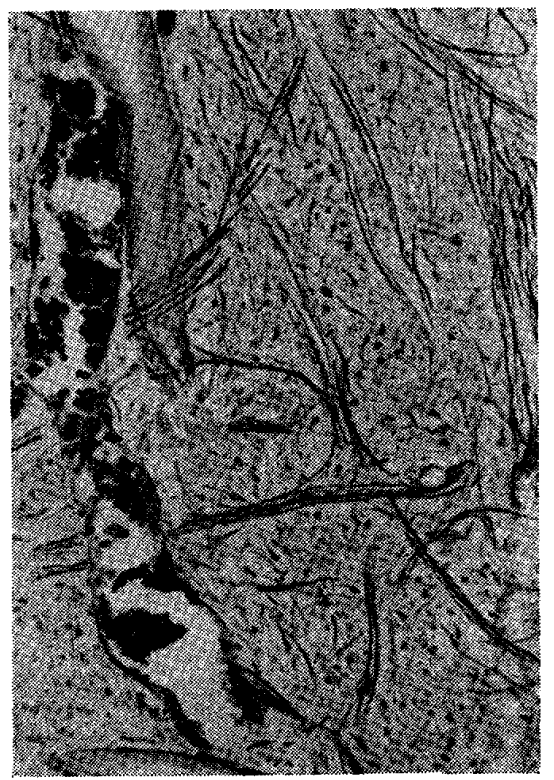

写 真 15
急性一部性化膿性歯髄炎は，今回著者が観察した33例中 17例，また，急性全部性化膿性歯蹃炎は16例であった。

急性一部性化膿性歯髄炎に颃いては, 好中球を主体と する炎症性細胞浸潤を伴う限局性化膿巣内にみられる神 経線維は, 膨化, 断裂, 染色性の低下などの変性に陥っ たものと，まだ健全な細い神経線維が混在して諗められ たが，全体的にその分布量の低下がみられた。

急性全部性化膿性霜髄炎においては，神経線維はその 径の大小にかかわりなくほとんどが膨化，断裂，蛇行お よび波状に走行するなどの変性に陥っており，なかには 顆粒状崩壊をおこし, 消失寸前の神経線維も多数認めら
れた・またててれらの変性に宿った神経線維とともに Schwann 細胞の増殖を伴なう神経線維も少数みられる が, 全体的に神経線維の分布量の低下がみられた。

このように急性全部性化膿性崡髄炎です 健全な 神 経 線維を少数ではあるが認めることができる（写真24〜 30).

\section{c. 急性壊徝性菌髄炎 (16例)}

急性壊疽性歯髄炎は滲出性の炎症に陥った甸髄に窝敗 菌が感染したもので，壊㡹に陥った部位の細胞は崩萝消 失し, 組織としての構造が全く失われているため, 神 経線維も例外でなく，すべて消失し，その痕跡すら認め 


\section{られなかった。}

壊疽組織に接する，壞死直前の組織内，および炎症性 細胞浸潤の渚しい残存粜髄組織内にみられる 神経線維 は，健康なものは全く認められず，残存する神経線維は その径の大小にかかわりなく全て膨化，断裂，蛇行およ び顆粒状崩壊に宿った所見を呈し，なかには消失，また は消失寸前でその痕跡を残す程度に変性に陥った所見も 多数認められた (写真 $31 〜 37)$.

\section{2 ）慢性菌檤炎}

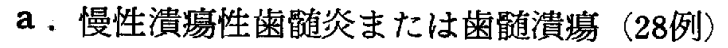

本症は歯髄が外界に露出している場合，歯㖪の表層に
潰煌を形成している場合をいい，歯骾の生活力が比較的 弱く, 細菌の毒性が強く, 常に新しく侵入して, 茵髄の 露出面に刺激を与えている.病理組織学的には，3 首に 区別される，すなわち，最表層には化膿層，その下方に 炎症性細胞の著しい浸潤を伴う肉芽組織層，そしてさら に，その下方に線維性結合組織層が認められる。乙の線 維性結合組織が 残存する 正常雨髄との境界となってい る。

神経線維は化膿層には認められなかったが，化膿首直 下の幼若肉芽組織層をとり囲むように細い神経線維が多 数みられる、極めて密な網状の分布を呈する所見が認め

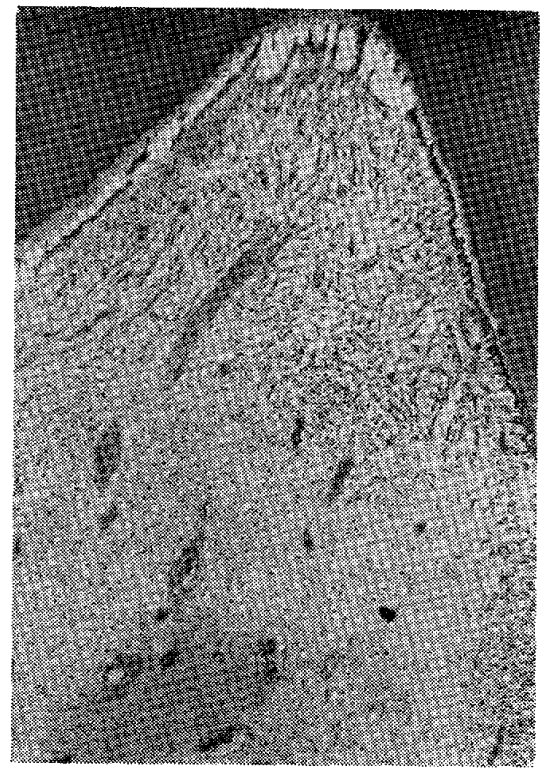

写 真 16

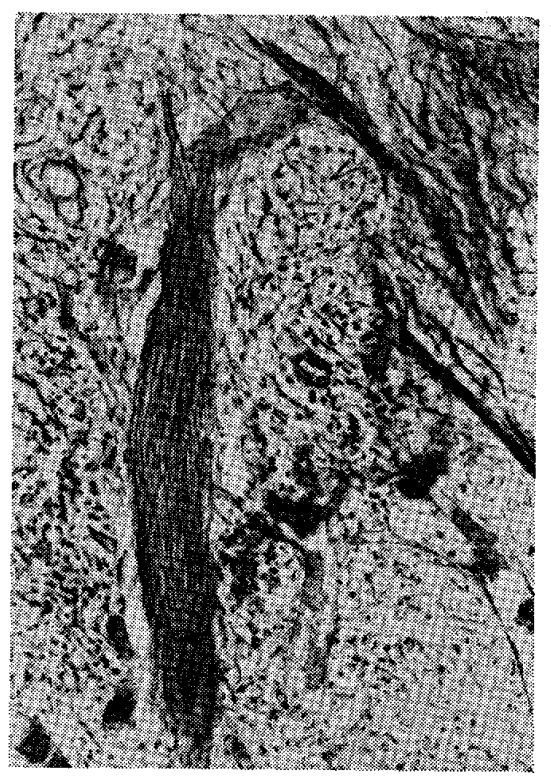

写 真 19

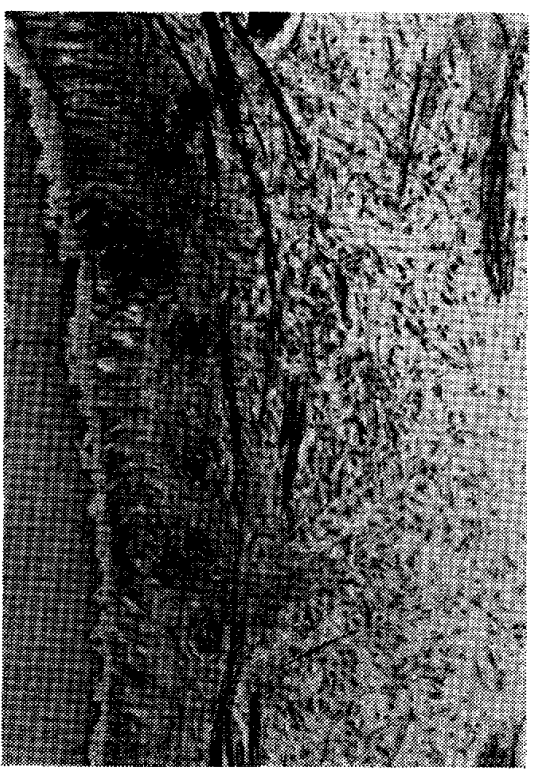

写 真 17

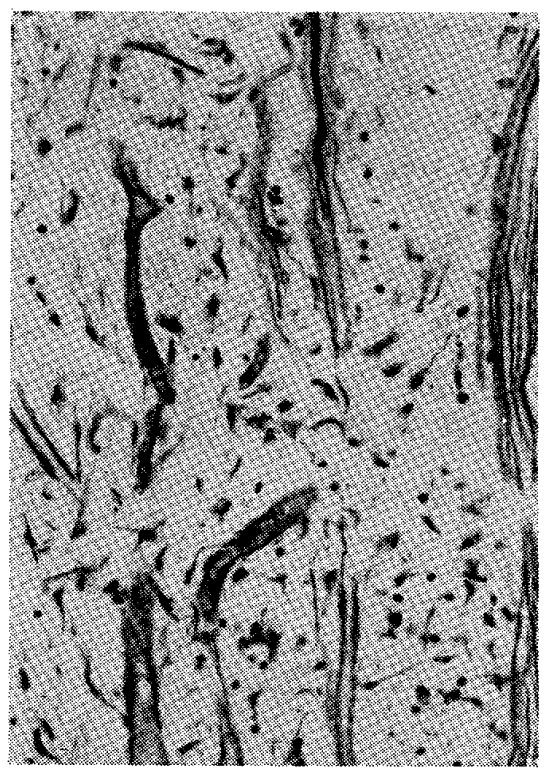

写 真 20

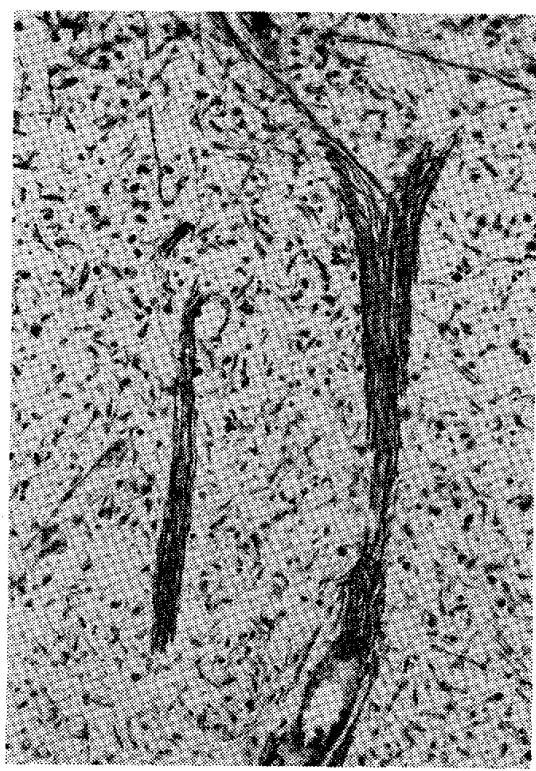

写 真 18

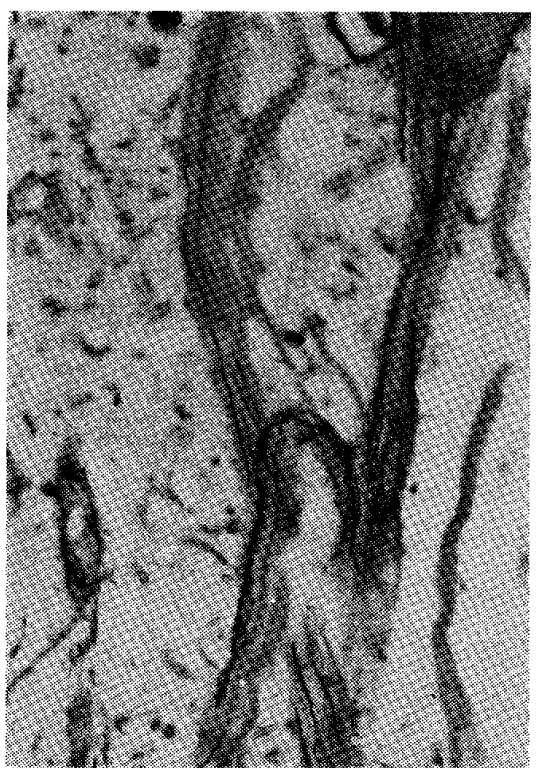

写 真 21 


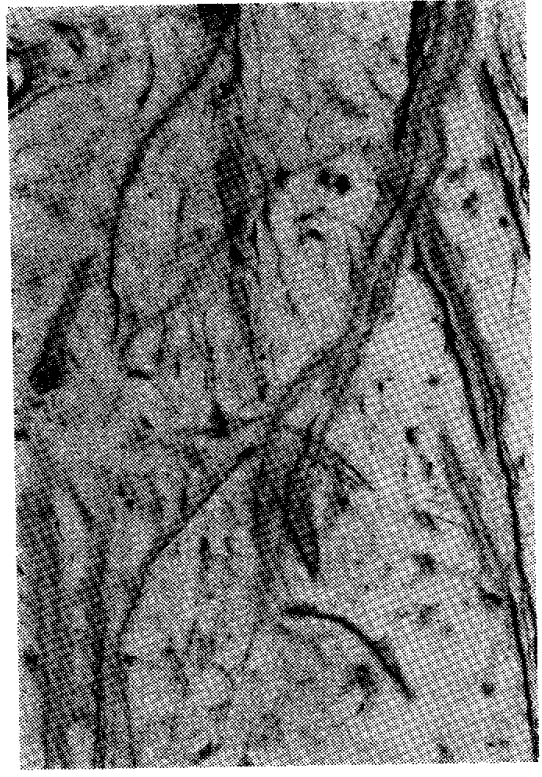

写 真 22

られた。これらの神経線維の中には膨化おる゙び染色性の 低下などの変性に陷ったものもみられたがそのほとんど は健全なものであった。

幼若肉芽組織層から線維性結合組織層にみられる神経 線維は膨化，染色性の低下および蛇行などの変性に陷つ たものと健全なるものとが混在してみられたが，その走 行は不規則で, また残存歯䯣内にみられる神経線維は健 康なものと比較して大差は認められなかった（写真38〜 46) .

b ．慢性増殖性橉髄炎または橉髄息肉（7例）

慢性増殖性歯髄炎は病理組織学的には表層から白血球

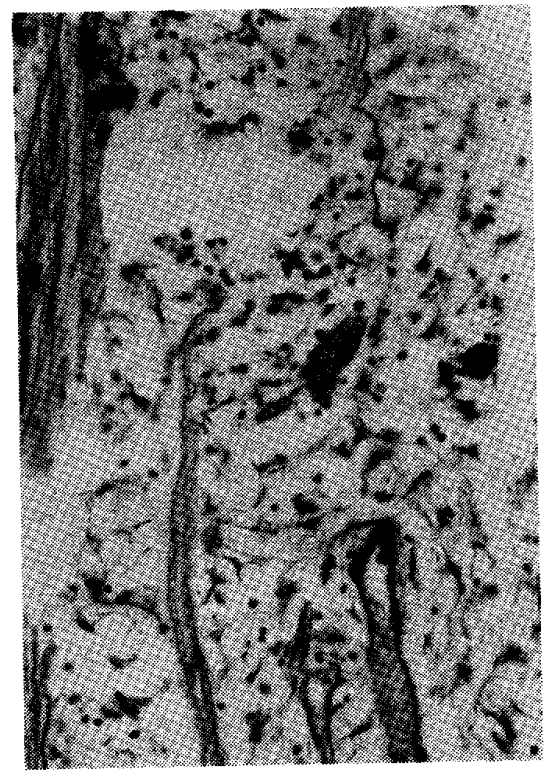

写 真 23
層あるいは上皮層，炎症性細胞浸潤を伴う幼若肉芽組織 層および線維性結合組織層の 3 層に区別される.

神経線維は白血球層直下の幼若肉芽組織層から白血 球首にかけての部位におろいて走行は不規則であったが， 極めて細い神経線維が認められ，乙れらの神経線維は膨 化，染色性の低下などの変性に宿ったものと，健全なも のとが混在して扔り，なかには白血球尿内に自由終末を 形成するものも誌められた。また，乙れよりわずかに下 方の幼若肉芽組織内では，上皮層に向って曾牙の長軸と 平行に走行する細い神経線維が多数認められ，てれらの なかには，健全なものも多数みられたが，全体に分布量

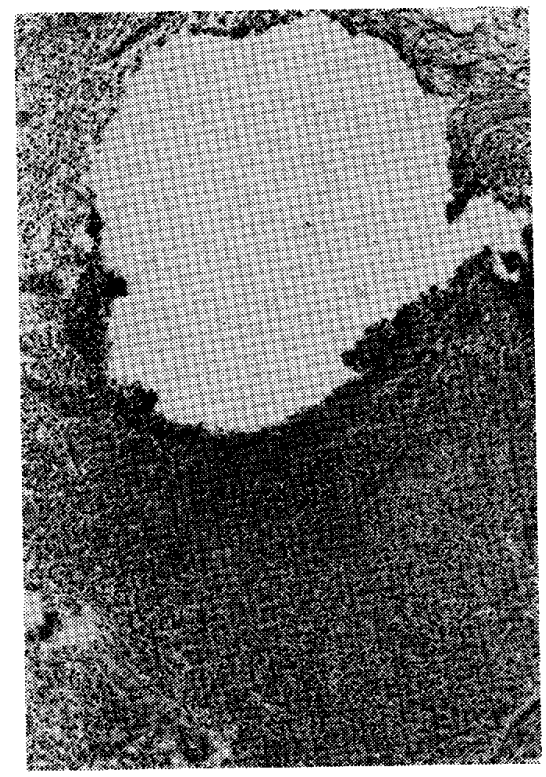

寻 真 24

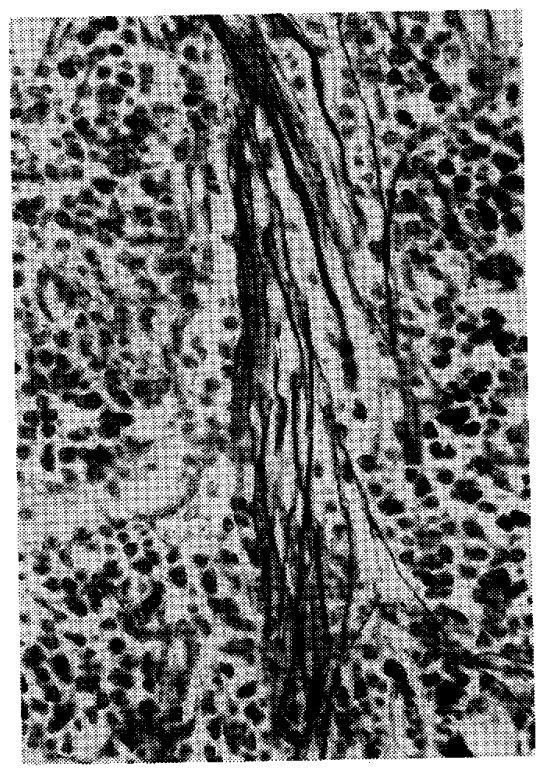

写 真 25

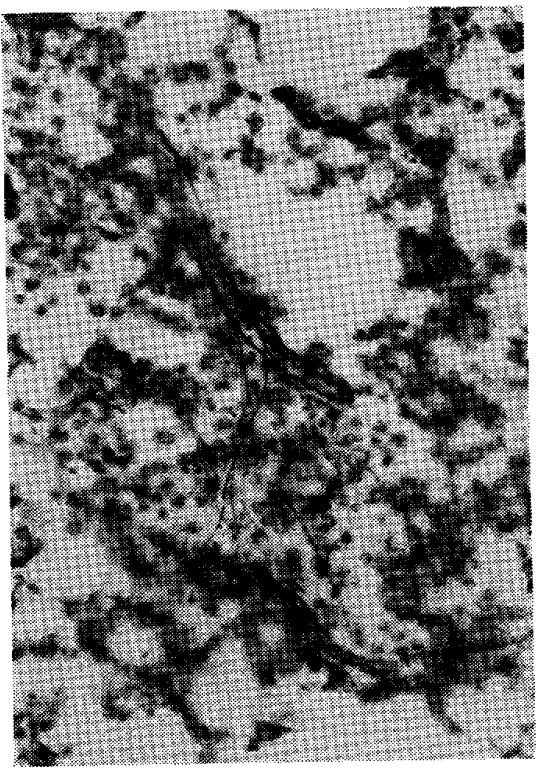

写 真 26 


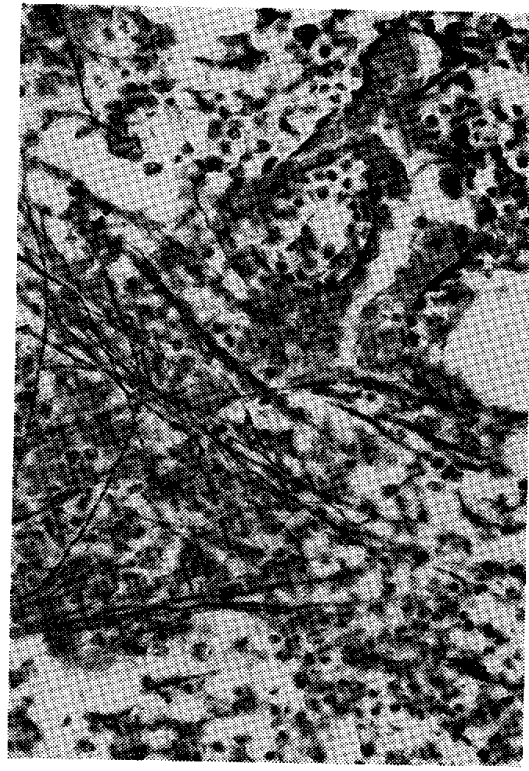

写 真 27

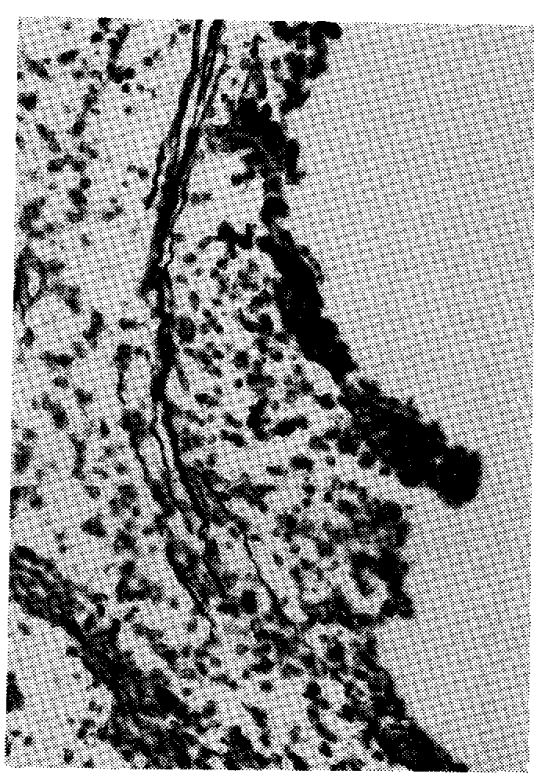

写 真 28

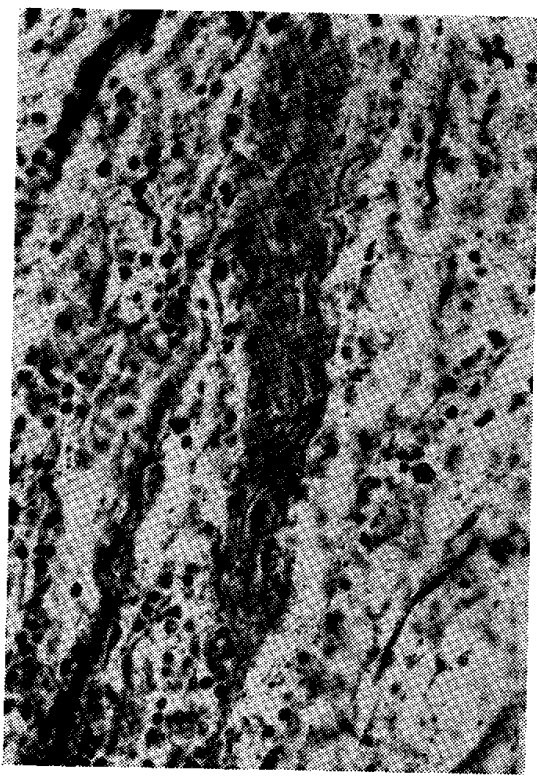

写 真 29

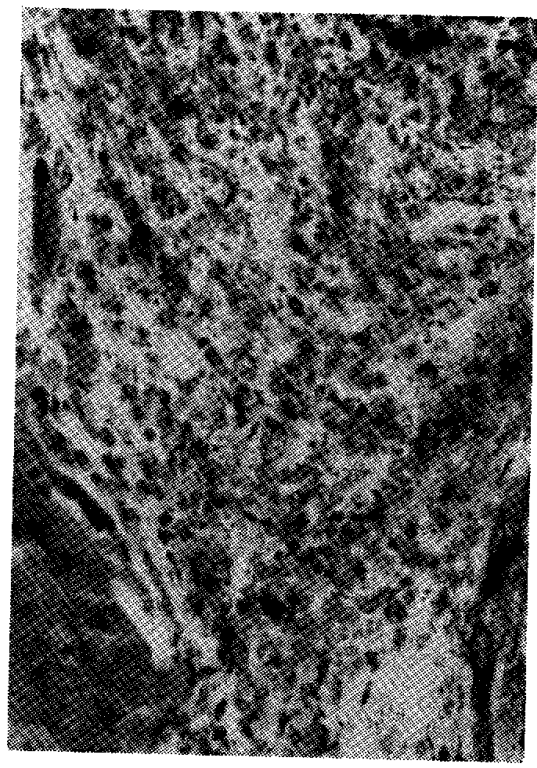

写 真 30

が少なく，染色性の低下が認められた。

幼若肉芽組織圈から結合織層にかけての部位において は膨化, 断裂, 蛇行, 染色性の低下などの種々の変性に 陥った神経線維とともに，增殖する Schwann 紐胞を含 む神経束や，Schwann 細胞力゙柵状に排列し， その間を 微細な神経線維が走行する Büngner 氏索を形成する神 経束が多数認められた。

根部菌髄における残存歯髄内の神経線維には正常のも のと比較して何ら異なる所見は認められなかった（写真 $47 \sim 53$ ) .

\section{c . 慢性閉鎖性雬髄炎（9 例)}

今回，著者の観察したのは 9 例で, 全て歯喵内に限局 性の膿瘍を形成している症例で，乙の場合歯髄の一部に 限局性の膿焬が形成されているとき，その部における細 菌の毒性が弱くなり, 膿瘍周囲に緻密な結合織, すなわ ち膿湯膜が形成されている。

神経線維はこの膿煌膜内に多数の微細なものが虫めら れ，これらは膿痬をとり囲さように網状に分布してお り，そのほとんどが健全な神経線維であった。

膿瘍周囲の軽度の炎症性細胞浸潤がみられる部位にお いては健康な神経線維とともに, Schwann細胞の堌殖 を伴う神経束も多数認められた。

また，その他の残存曾髄内に抢いては神経線維に著変 は認められなかった（写真54，55）。

IV. 退行性病変

1) 空胞変性 (8 例)

この変性は主に象牙牙細胞に認められ，歯髄細胞には まれである・まず, 象牙芽細胞の原形質に球状の微小空 胞が生じ, 漸次ての数, 大きさを増し, 細胞間にも液状 成分の町溜をきたし，乙れが増量するにしたがい，象牙 牙細胞は圧迫されて半月状を呈している。

このような空胞変性に陥った象牙牙細胞層内に進入す る神経線維は軽度に膨化した所見を呈するものもみられ たが,はとんどの神経線維には著変は認められなかった。

Raschkow の神経叢を形成する神経線維にも若干の 変狌に陷った所見はみられたが，そのほとんどは健全な ものであった（写真56〜60）。 


\section{2 ) 石兏変性 (10例)}

石灭変性は, 結合織線維, 血管壁あるいは神経束など に不定形，顆粒状に石厕が沈着するもので，主に根部歯 髄にみられる。

石灰変性に陌った神経線維は，そのほとんどのものが 膨化，断裂および顆粒状崩萝などの変性に陥り，なかに は，消失寸前のものも数多く観察された。

また，石圧変性が軽度なものでも，神経線維が受ける 損傷は大きく，膨化，䉼裂あるいは染色性の低下などの 変性に陥っており，健全なものはほとんどみられなかっ た（写真61～65).

\section{3）網梯萎縮（29例）}

網様萎縮は象牙芽細胞層の空胞変性が歯䯣中央へ進展 して歯髄組織が網様を呈した状態であるが, 神経線維は 網様萎縮がまだ歯䯣全体に広がる以前の初期のすので は，網様萎縮内やそれと接する 健康歯髄内には 変性に 陥った神経線維とともに未だ健全なものが多数認められ る。

しかしながら，網様萎縮が菊髄全体におよぶようなも のでは，神経線維は全てが空胞形成，染色性の低下，あ るいは顆粒状崩壊をおてし，消失寸前の所見を呈してお り，健全な神経線維は全くみることが出来なかった（写

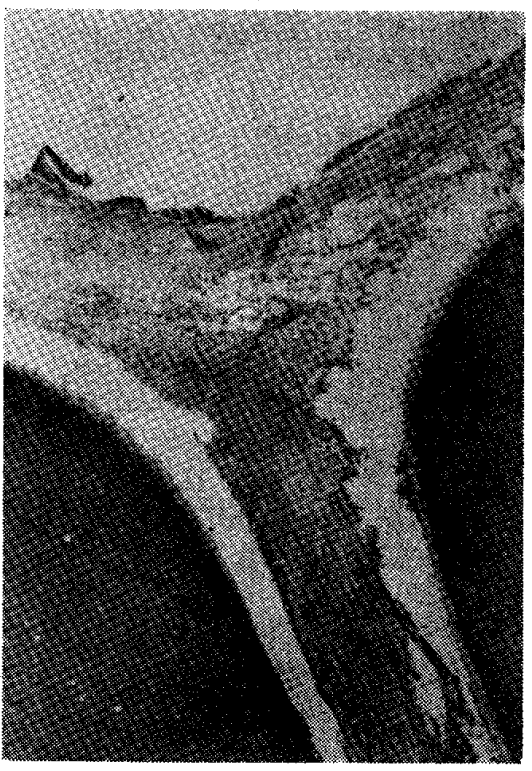

写 真 31

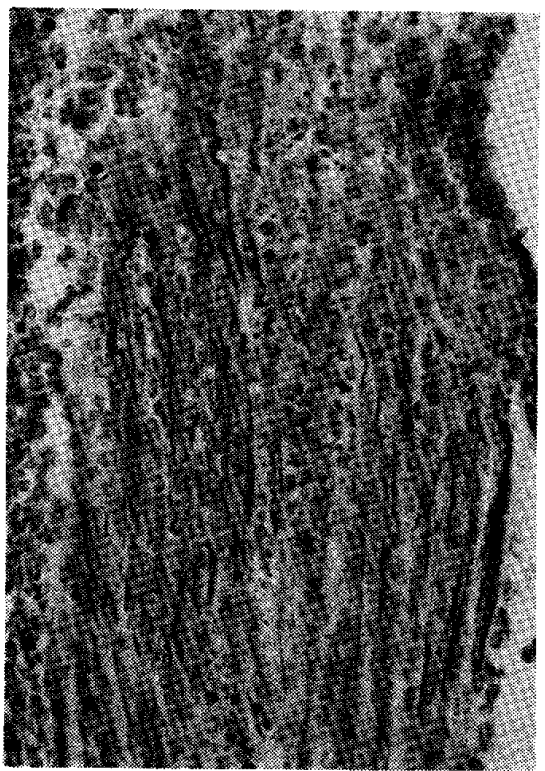

写 真 34

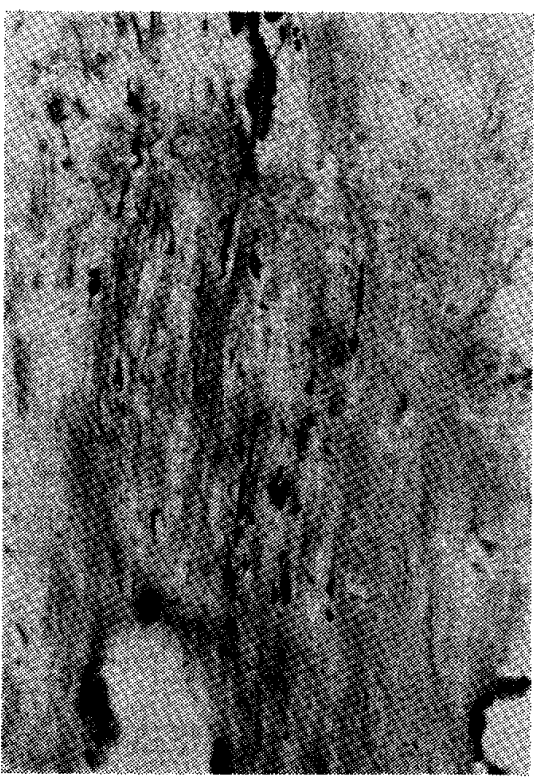

写 真 32

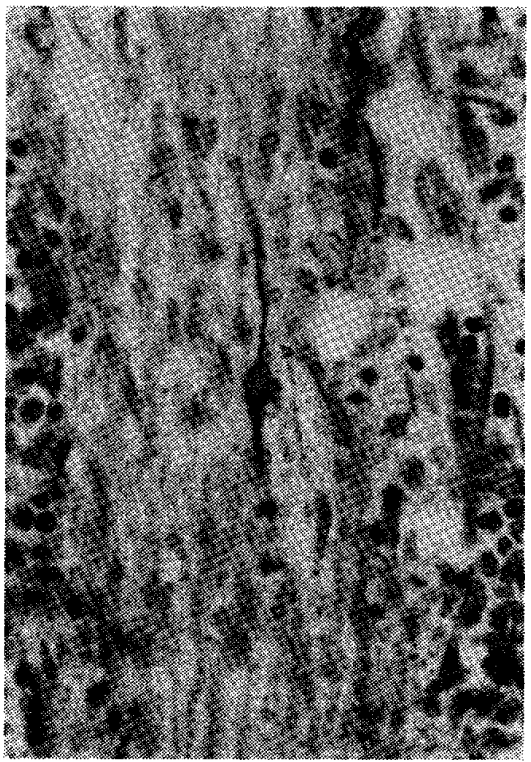

写 真 35

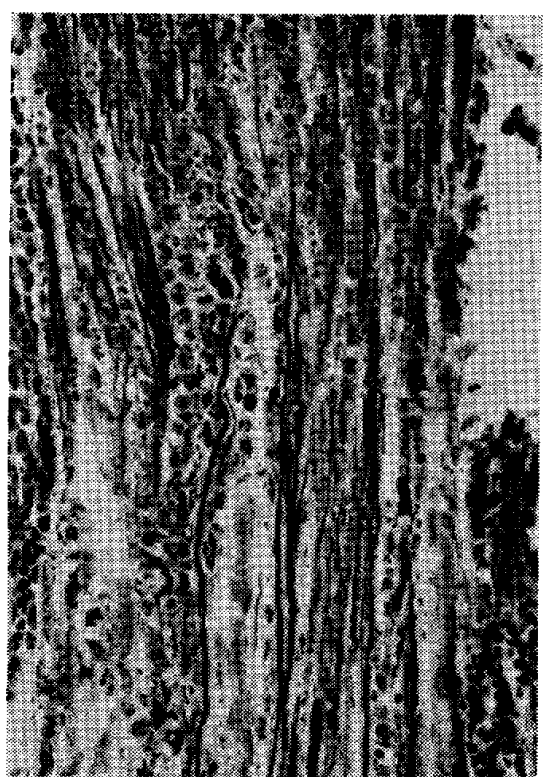

写 真 33

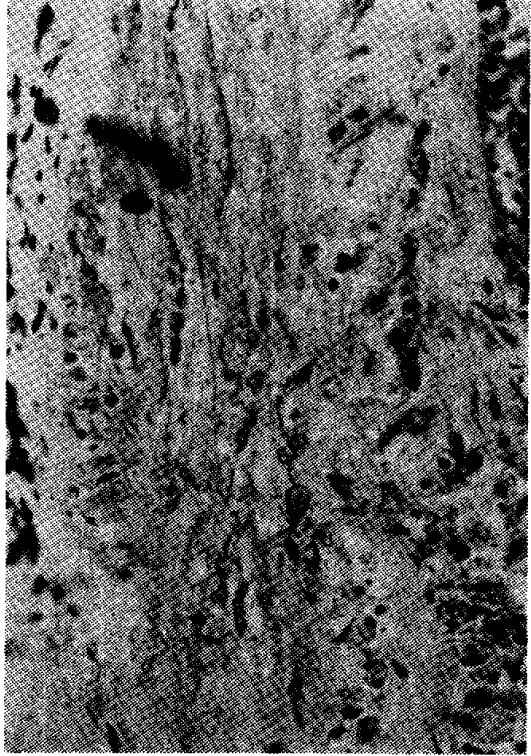

写 真 36 


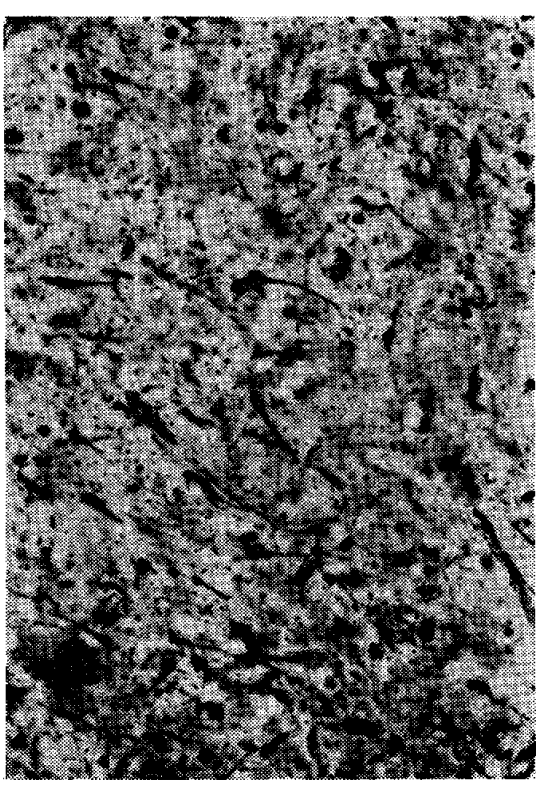

写 真 37

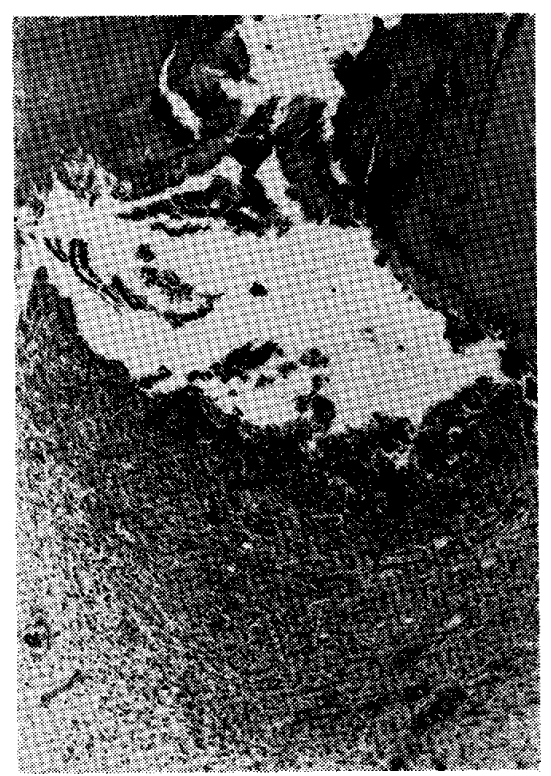

写 真 38

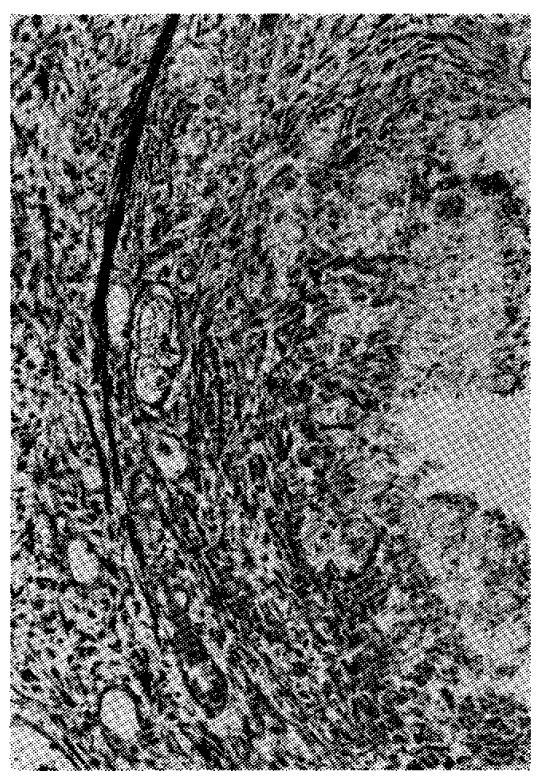

写 賣 39
真66 71).

\section{総括ならびに考察}

健康曾髄ならびに歯䯣疾患時の米牙内神経の動態につ いて観察を行ったが，便宜上，歯髄充血，急性雨髄炎， 慢性霜髄炎 および 退行性病変の 4 項目に分けて考察す る。

\section{1) 兩髄充血}

歯骮有充血時に抢ける歯牙内神経線維は充血が初期のも のでは著変は認められなかった。

充血が永続する場合, 充血によって惹起された水腫内
を走行する神経線維には，膨化，染色性の低下，念珠状 変化および不規則な走向といった所見が認められたが， これらは主として径の太い神経線維に認められ, 径の細 い神経線維はそのほとんどが健全なものであった。

岡部 $(1937)^{21}$ は㐘骮充血時においては，神経線維， とくに髄鞘には全く変化は認められなかったと報告し， 内田（1959） 18) は若干の退行性変化が神経線維に認めら れたが，てれらは正常曾䯋における所見でもみられるも のであり，充血によるものとしては認められなかったと 述べている. Plačková(1966) 23'は神経線維が受ける 最初の変化は好銀性の増加であり，料髄充血時には神経

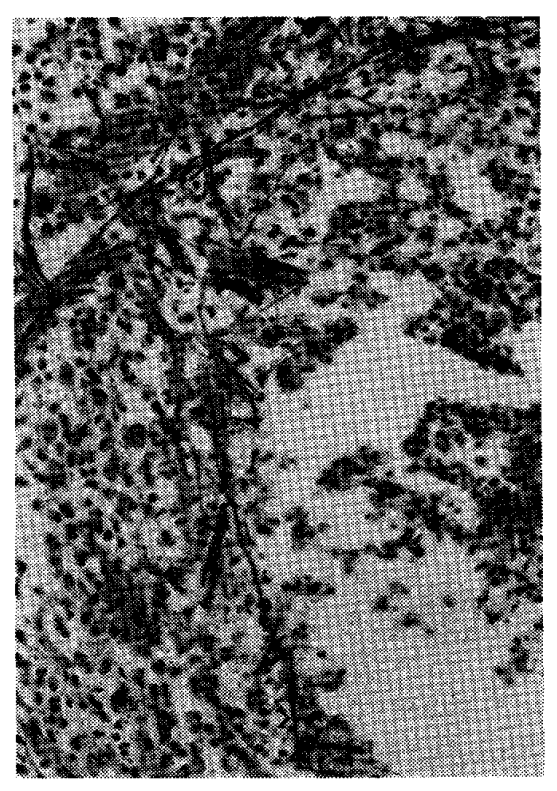

写 真 40

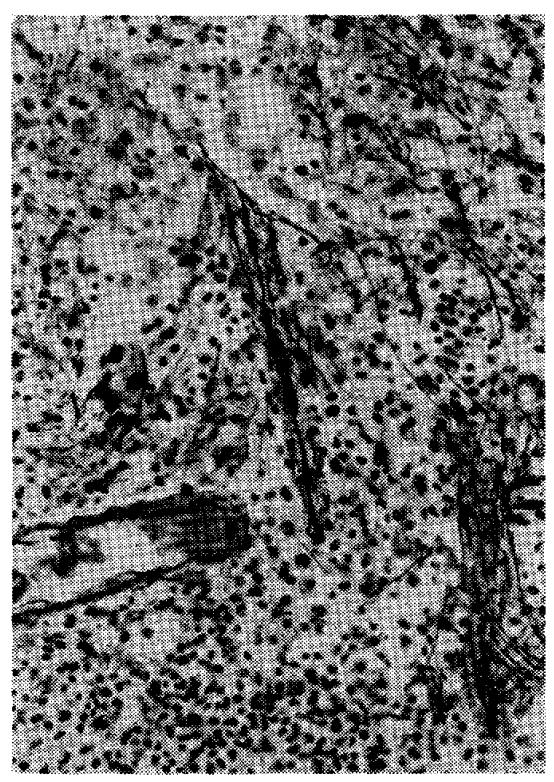

写 真 41

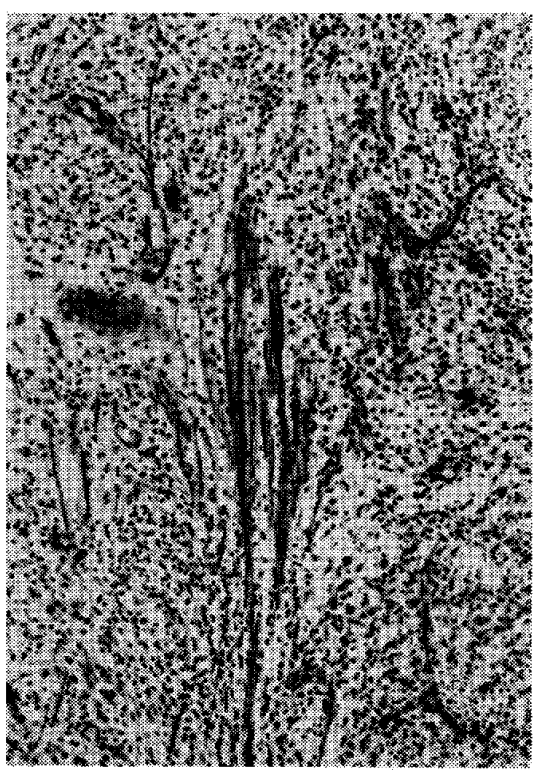

写 真 42 


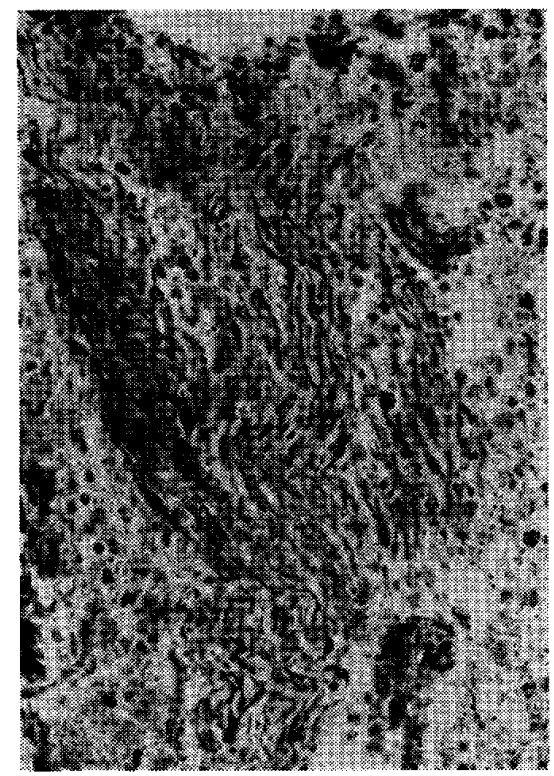

写 真 43

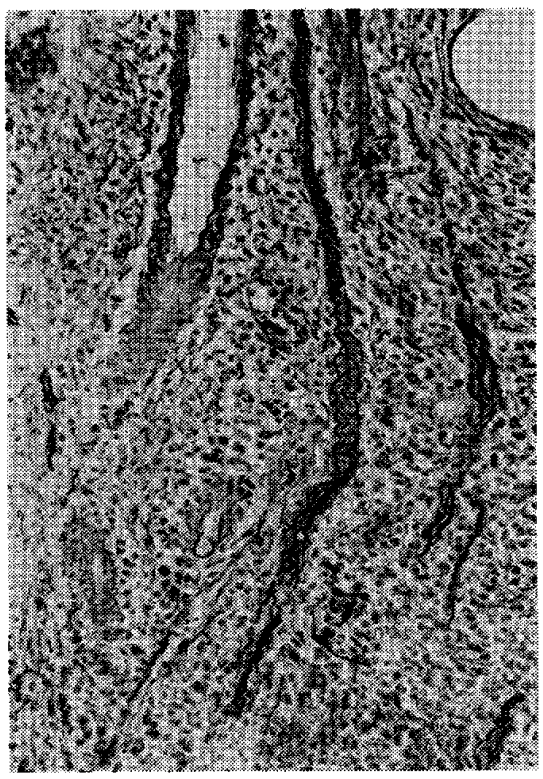

写 真 44

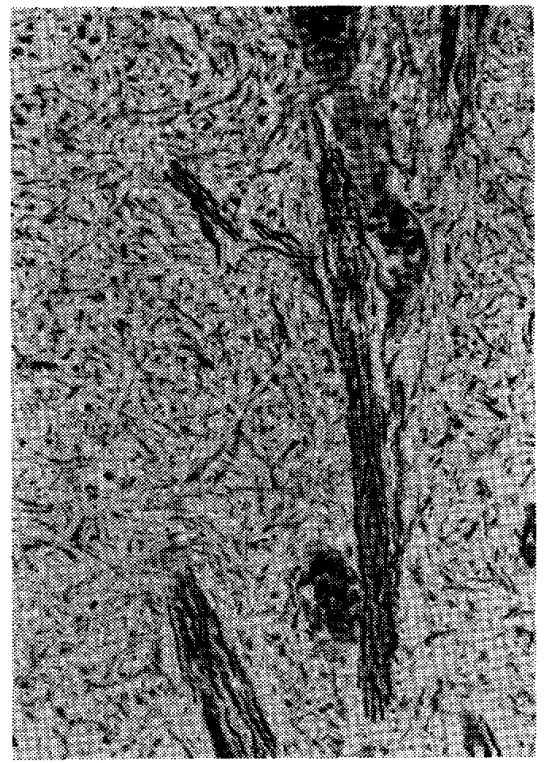

写 真 45

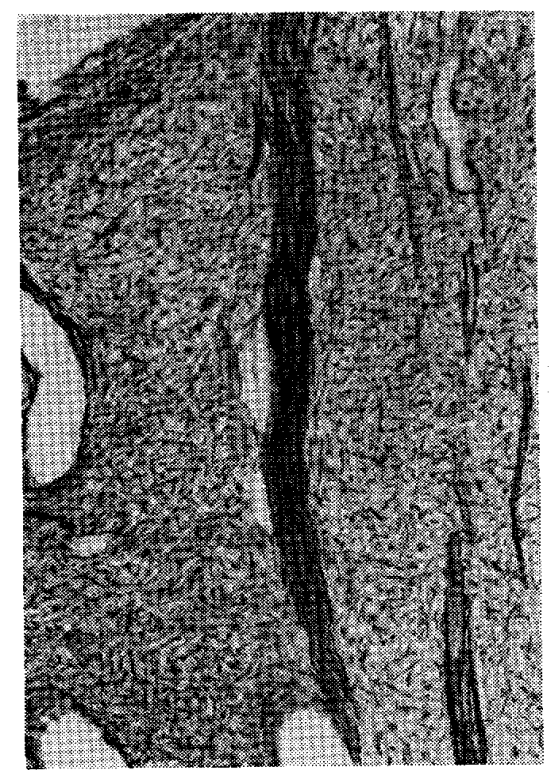

写 真 46

線維に著変は珰められなかったが，乙の好銀性だけが 著明になったと報告している．著者の観察結果からは Plačková (1966) ${ }^{23}$ ) のうう好銀性の増加を証明するこ とは出来なかったが, 充血初期において神経線維に著変 が喼められなかったという点においては岡部(1937) 21)， 内田 (1959) ${ }^{18)}$ および Plačková (1966) 23) らの研究を 確証するものであった，また，充血が永続するような症 例については，その報告例が全くないため, 今回は比較 検討することは出来なかった。

\section{2）急性䨑䯣炎}

急性墏液性篓髄炎では炎症巣内およびその周囲を走行
する神経線維は膨化, 染色性の低下あるいは蛇行するす のなどがみられたが，これらのほとんどが径の太い神経 線維で, 径の細い神経線維は大多数が健全なものであっ た、また，全部性獎液性菌髄炎では変性に陥った神経線 維とともに，堌殖するSchwann 細胞を含む神経束が認 められた。

急性化膿性歯髄炎の場合，炎症が蒾髄の一部に限局し ている化膿巣およびその周囲にみられる大小の神経線維 は赴化，断裂，染色性の低下などの変性に陷ったもの と，末だ健全な細い神経線維とが混在して認められた。 化膿性炎症が歯䯣全体におよぶ全部性歯檤炎では，神

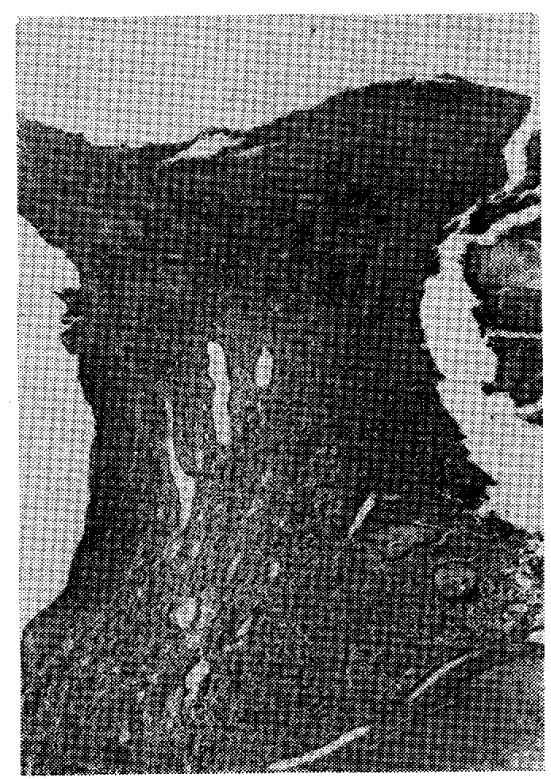

写 真 47 


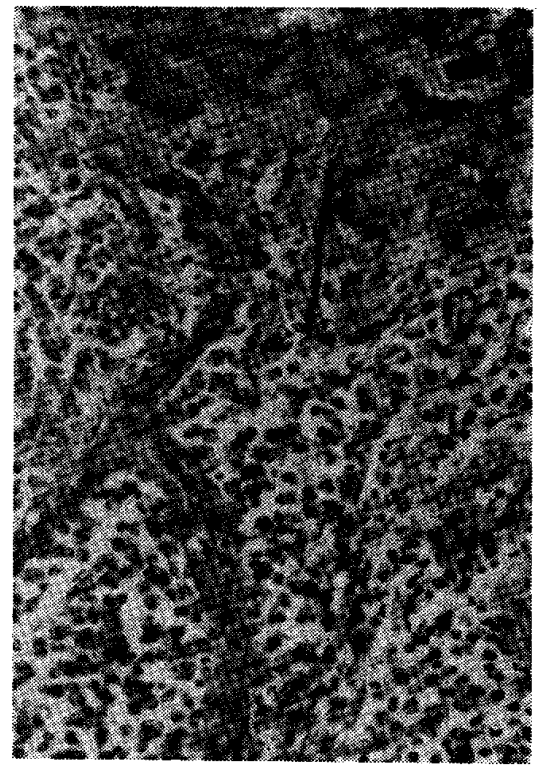

写 真 48

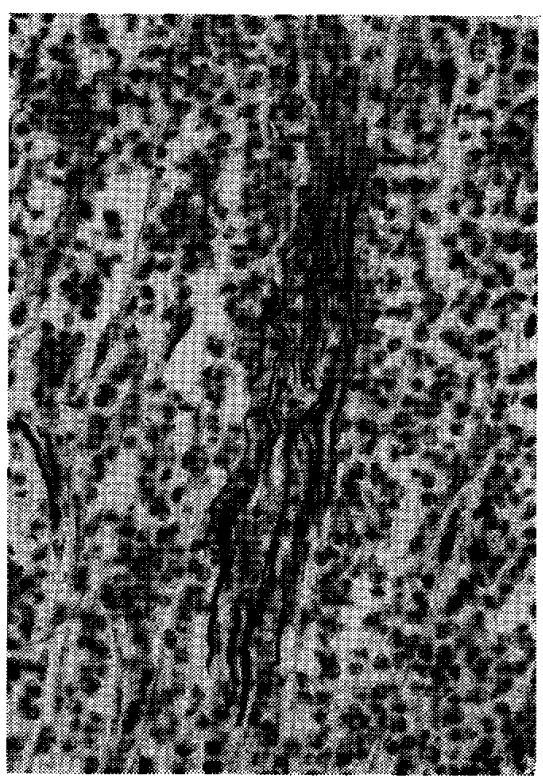

写 真 51

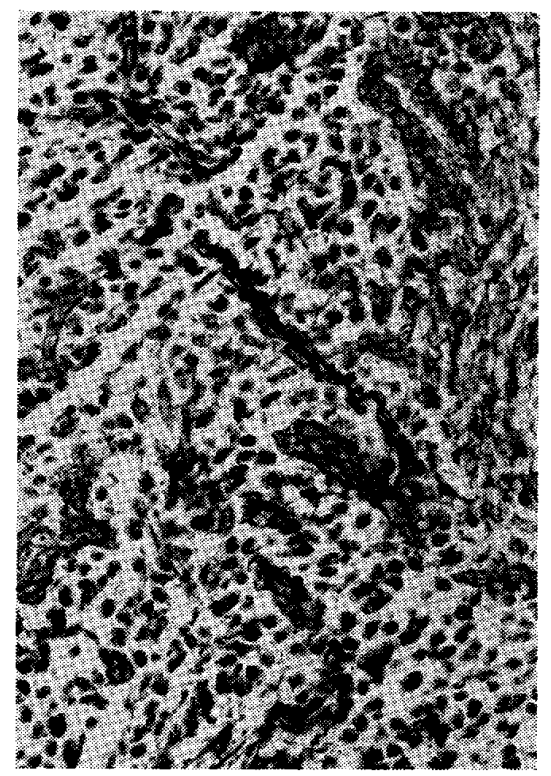

写 真 49

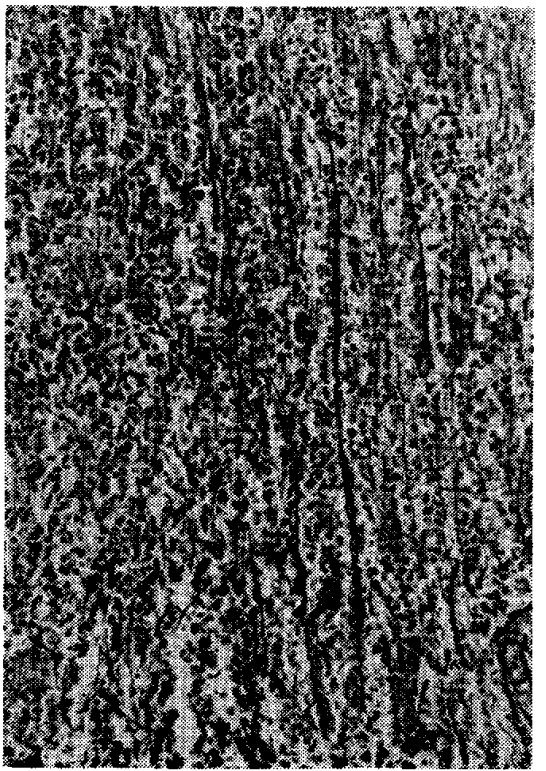

写 真 52

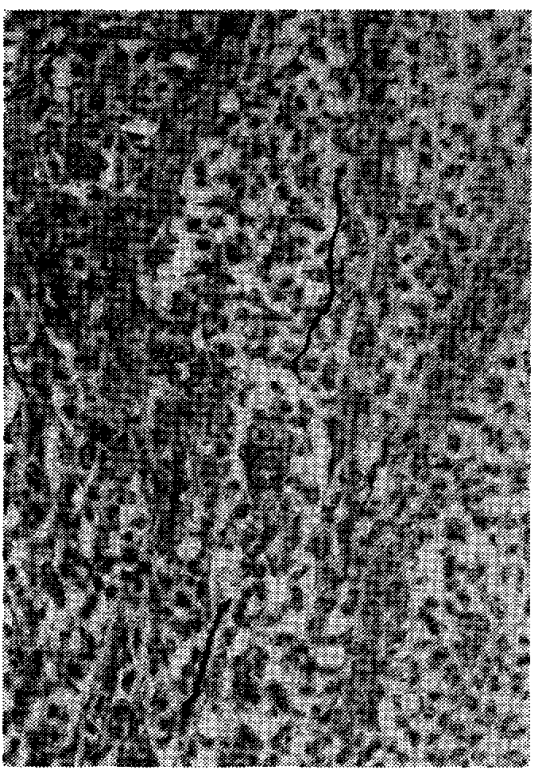

写 真 50

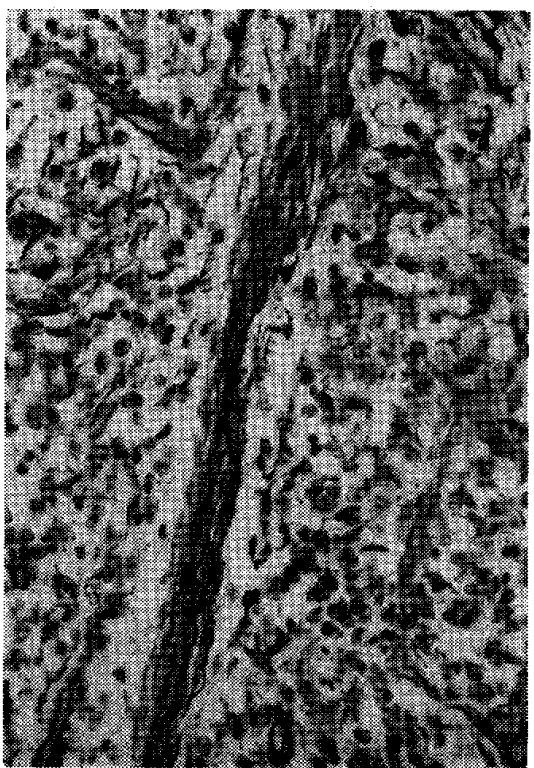

写 真 53
線経維は径の大小にかかわりなくそのほとんどが膨化， 断裂，蛇行などの変性に陥り，なかには顆粒状崩壊をお こし，消失寸前の神経線維も認められ，これらの変性に 陥った線維とともに未だ健全な神経線維も少数みられ た。また，化膿性㐘髄炎では全体的に神経線維の分布量 の低下が認められた。

急性壊瘨性菌髄炎では，壊死直前の組織内および炎症 性細胞浸潤の著しい残存歯髄組織内にみられる神経線維 は健全なものはほとんど認められず，残存する神経線維 は全て断裂，蛇行および顆粒状崩壤の所見が認められ， なかには消失寸前のものも多数認められた。
歯骾の炎症によって米髄内の神経線維が蒙むる変性に ついてPlačková (1966) ${ }^{23}$ は炎症および膿埸形成がみ られるものでは神経線維は好銀性の增加，静脈瘤様腫 脹，走行の不規則および顆粒状崩壊などの変性に陥り，

炎症が更に激しくなると神経線維は断裂を打しすと述 べ, Bernick $(1972)^{26}$ も炎症等に隣接した部位では神 経線維は変性に宿っていたと報告している．著者の観察

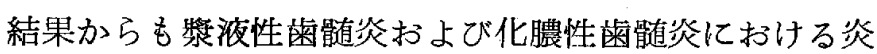
症巢およびその周囲にお污神経線維はその多くが膨 化, 断裂, 蛇行, 染色性の低下などの変性に陷った所見 ならびに分布量の低下の所見がみられ，炎症が著しいも 


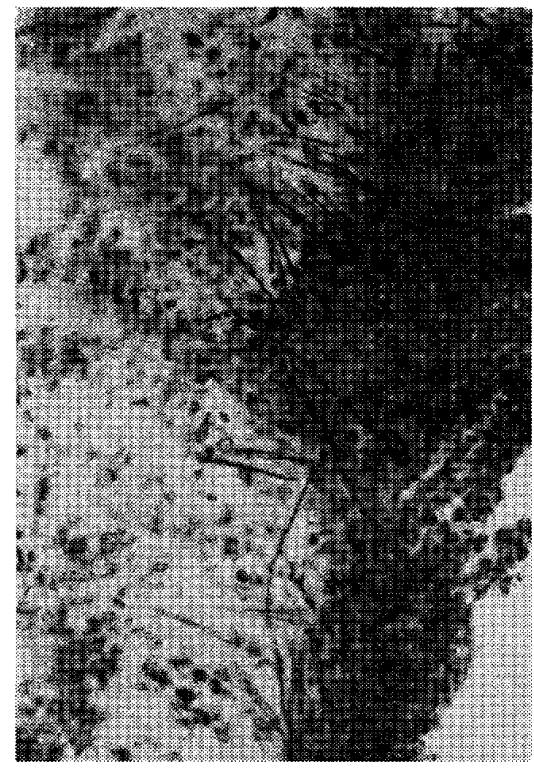

写 真 54

のでは消失または消失寸前の神経線維も数多く認めら れた。これらの事実は Plačková (1966)23)，Bernick (1972) 26) らの結果を裏付けるものであった。しかしな がら，著者の観察結果で最も興味があったのは漿液性㐘

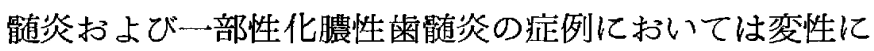
陷った神経線維とともに健全な神経線維が多数存在した という事実である．との点について Almeidaら（1973） 27)は炎症性細胞浸潤の著明な部位において 神経線維は 顆粒状変化を伴う静脈瘤様腫脹や断裂を示し, てれらの 変性した神経線維に沿って大食細胞とSchwann 細胞が 観察され，一部では完全な消失の所見すら認められたと している、しかしながら，てれに反して，特々一本の神 経線維が炎症部分を横切り，まっすぐに走行する所見が 認められたと述べ，さらに神経線維は破壊的な炎症過 程において歯髄内で消失する最後の要素であると思われ ると報告している. 内田（1959） ${ }^{18)}$ もまた，白血球など の炎症細胞浸潤が著しい部位で部分的に残存する神経線 維を認め，それらは主に太い神経線維の檤鞘であったと 報告し, England ら (1974) ${ }^{29}$ は不可逆性雪髄炎では 神経線維は変性に陌るが, その程度は周囲組織より軽度 であり, 神経線維は本質的に無傷で, 知覚伝導能を有し ており, 神経線維は周囲組織よりも長く変性に対し抵抗 性を有する。しかしながら，壊死に陥った症例では神経 線維は変性, 消失し, 伝導能も有していなかったと述べ ている. Torneck (1974) ${ }^{28)}$ は初期の雬髄炎では神経 線維の変性と破買は周囲組織より後で扟てると述べ，て れらの原因は神経線維のある部位に存在するコラーゲン と他の組織のコラーゲンと異なる抵抗性を有しているた

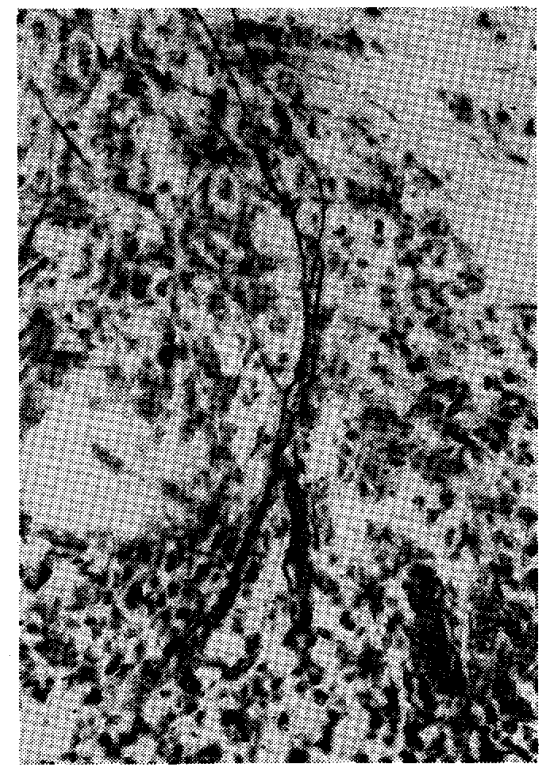

写 真 55

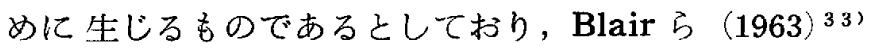
も同様の報告をしている，とのように神経線維が菌髄炎 に骝った際に長く存在するという報告例は多く， Rapp ら (1967 $)^{34}$, Martinelli ら $(1970)^{25)}$ 等によっても同 し様に報告されており，乙れらの事実は著者の観察結果 と一致するものであった。

神経線維が変性を受ける時に内田 $(1959)^{18}$ は先にも 述べたように，太い神経線維の檤鞘が後期まで残存した と述べ, Young $(1942)^{36)}$, Cajal (1959) 35' および迫 出 (1976) ${ }^{37)}$ らも最初に変性に陷るのは細い神経線維 であると報告している，しかしながら，渡辺ら（1956） 38'は変性の進行速度が, 大, 中, 小径の神経線維では 相違して扔り，この違いによって小经神経線維が最後ま で存在すると述べ，安藤 $(1980)^{39)}$ も変性を受けた太い 神経線維に混って健全な細い神経線維を多数認めたと報 告しておうり, 今回, 著者の観察結果は渡辺ら $(1956)^{38)}$, 安藤 $(1980)^{39)}$ の報告を裏付けるものであった。

壊死に陹った歯䯣内における神経線維について Mullaneyら $(1970)^{24}$ は彼が観察した48例に関して， 2 例が正常所見，12例が変性を蒙むる所見を呈し，34例 に神経線維の消失がみられたと述べている。また，先に 述へたように England ら (1974) ${ }^{29 !}$ 壊死に陷った組 織内では神経線維は変性消失したと報告している.今回 の萆者の観察でも，乙れらの報告例と同様の所見を呈 し, 壊死組織内ではいかなる神経線維も存在し得ないと いうことを証明するものであった。

3) 慢性氣骵炎

次に慢性の歯髄炎について総括すると，潰瑒性柬粷炎 


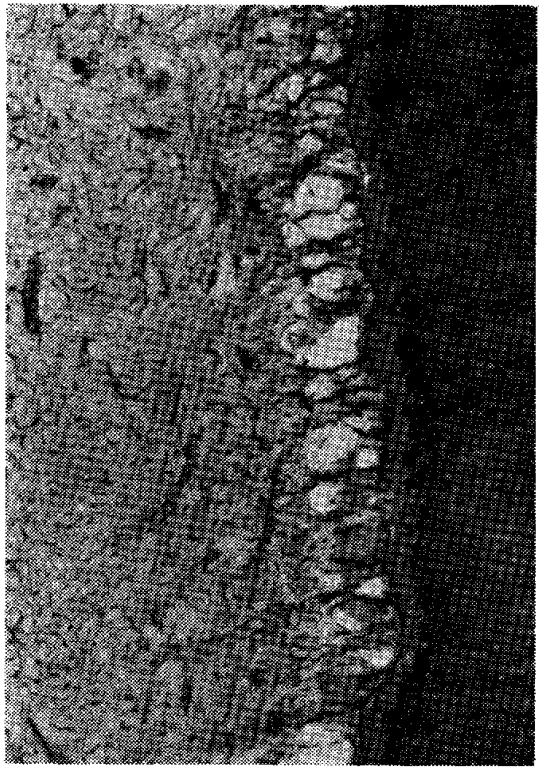

写 真 56

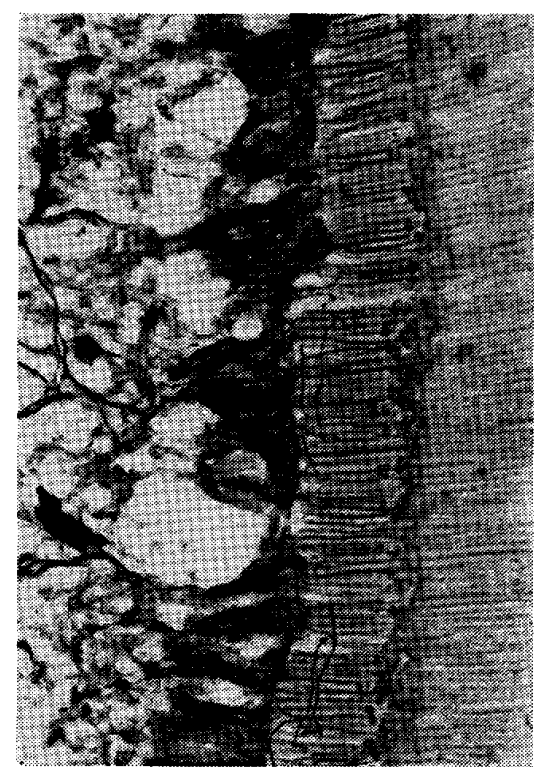

写 真 57

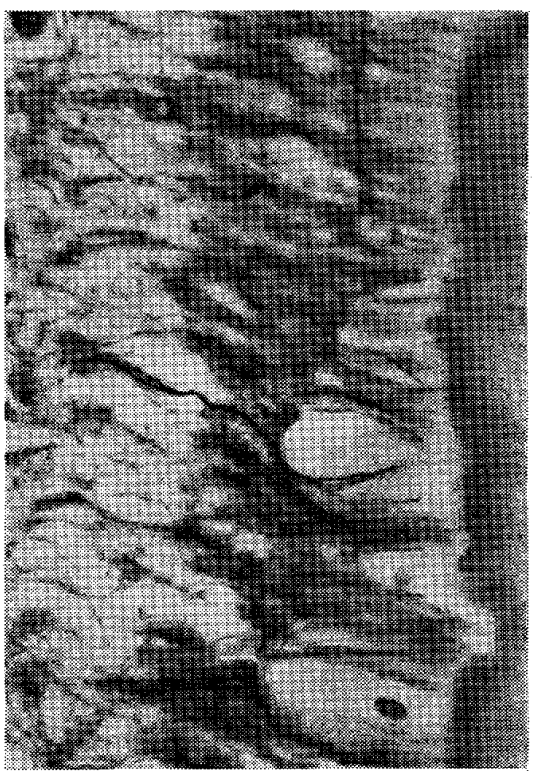

写 真 58

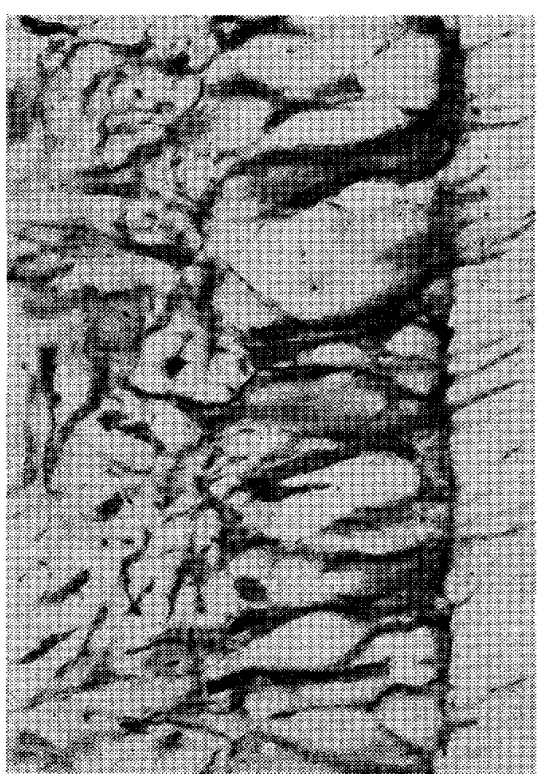

写 真 59

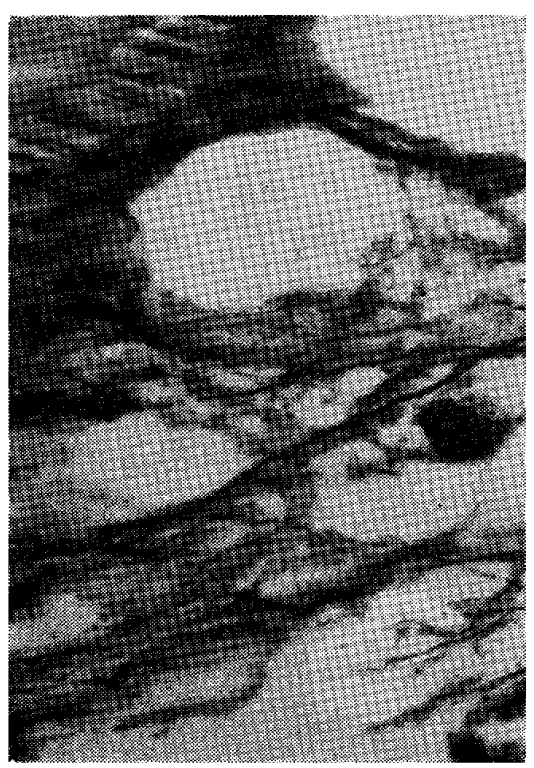

写 真 60
では化膿層と接する幼若肉芽組織層内に細い神経線維が 多数認められ，乙れらは極めて密な網状分布を呈してい た。これらの神経線維は若干の変性に陥ったものむ認め られたが，ほとんどのものは健全な神経線維であった。 幼若肉芽組織層から結合組織屠にかけては膨化，蛇行， 染色性の低下といった所見を呈する神経線維と健全なる のとが混在して認められたが，その走行状態は不規則で あった。

慢性増殖性菌髄炎では雪髄露出面が白血球首もしくは 上皮層で覆われているが，幼若肉芽組織層から白血球涕 にかけて，極めて細い神経線維が琶められ，これらの神
経線維は膨化および染色性の低下などの変性に陥ったも のと健全なるのとが混在してみられ，ながは白血球读 内に自由終末を形成するものも羿められた。 また, 幼若 肉芽層から上皮層に向って走行する細い神経線維が多数 認められ，健全なものも多数みられた。

幼若肉茅組織層から結合織首打よび残存健康蒾髄内に かけての部位では，変性に陷った神経線維とともに增殖 する Schwann 細胞を合む神経束や，柶状に配列した Schwann 細胞の中を微細な神経線維が走行する Büngner 氏索を形成する神経束とが混在して認められ た。 


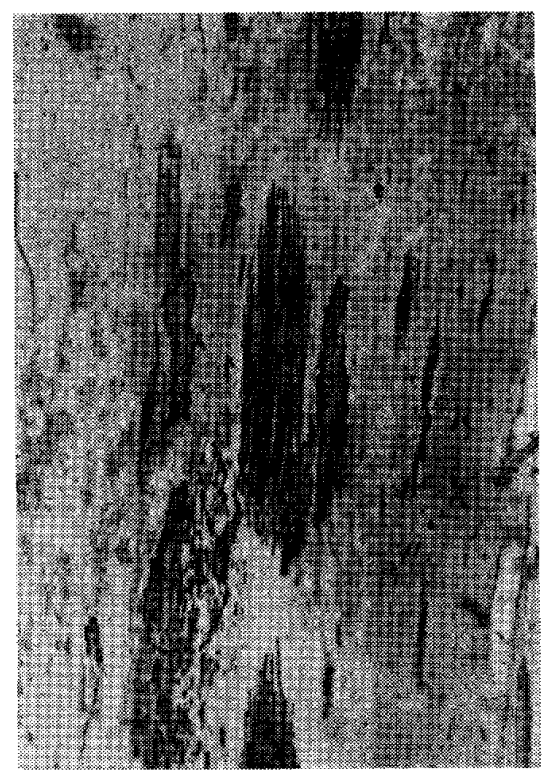

写 真 61

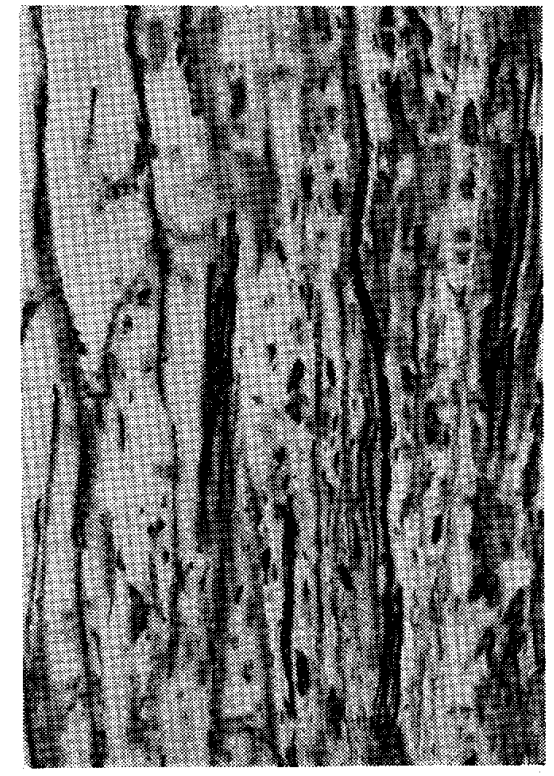

写 真 62

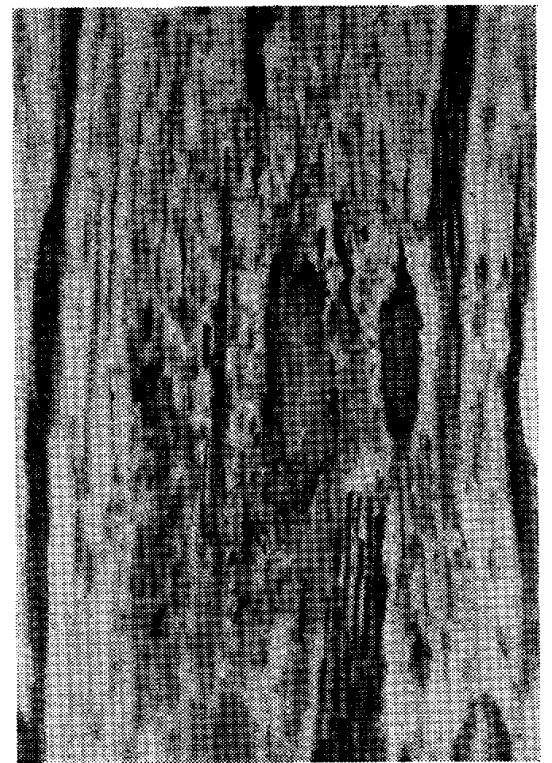

写 真 63

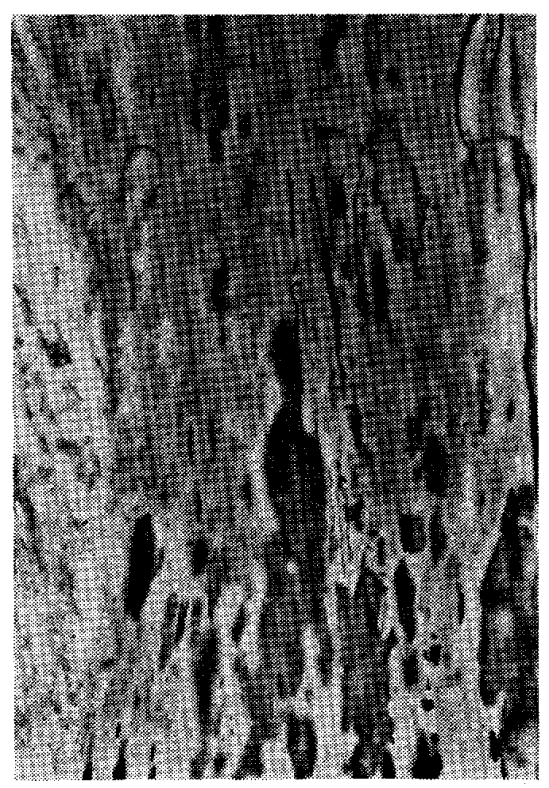

写 真 64

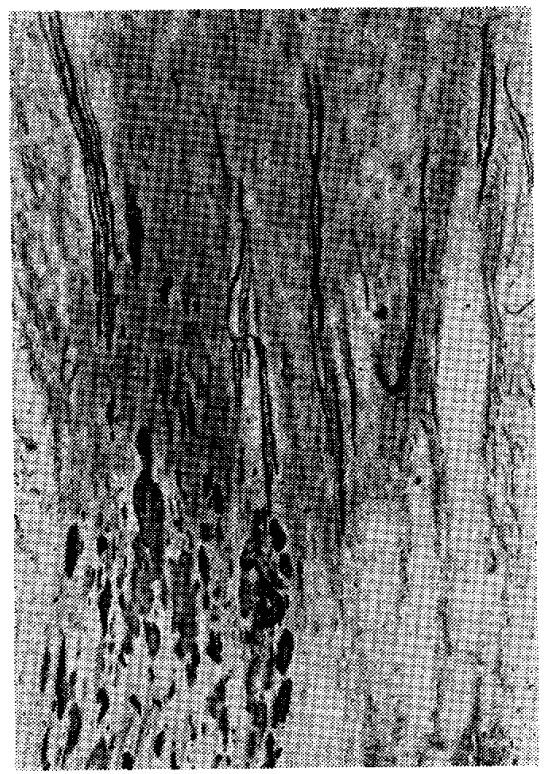

写 真 65

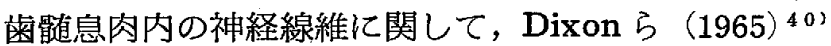
はPolypの結合織内および上皮組織内に神経線維の存在 を涊めることは出来ず，わずかに肉牙組織内に小さな無 髄神経束を認めたにすぎないと述べ，てれらの働きにつ いて血管の自律神経によるコントロールおよび軽度の知 覚性と関連があると思われると報告している．Römer (1909）42）は歯蹎息肉に存在する神経線維はわずかで， 息肉が根管と続いている部位にのみ存在すると述べ, Pucci ら $(1944)^{41}$ もとれと同様の報告をしている。 また Varella ら (1963) ${ }^{43}$ は肉芽組織内に神経線維は 存在せず, 歯髄息肉の痛みは咬合時の根部歯髄の神経線
維の圧迫によるものであると説明している。

これらの意見に対して岡部 $(1940)^{22}$ は雬哊息肉内に は有髄，ならびに無骾神経線維が存在するが，その走行 は極めて 不規則で著しく迂曲していると述べており， Martinelli ら $(1970)^{25}$ も类髄息肉に抢ける神経線維 について，根尖孔より息肉に向い上昇した神経線維，ま たは神経束は息肉内を通り，上皮組織に接する部位まで 達する、そして, 肉芽組織内では，てれらの神経線維は 急性炎症のある部位に接していても変性を示さなかった と述べている。

このように古くから米䯣息肉内の神経線維の存在につ 


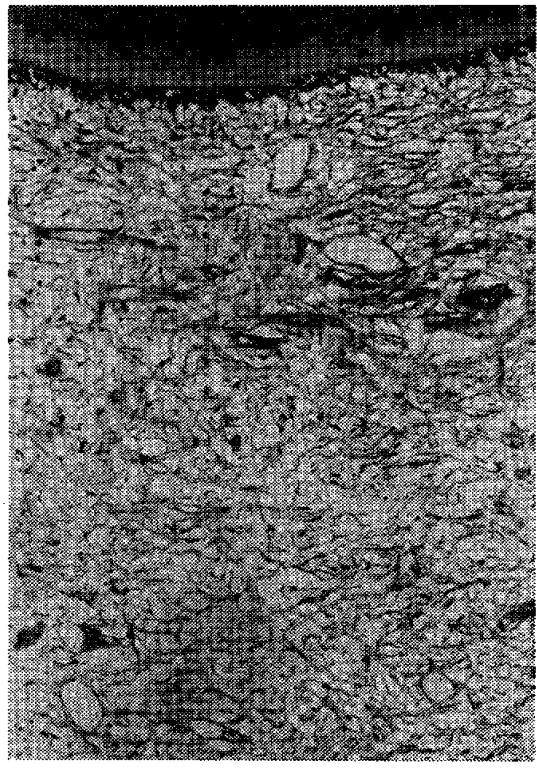

写 真 66

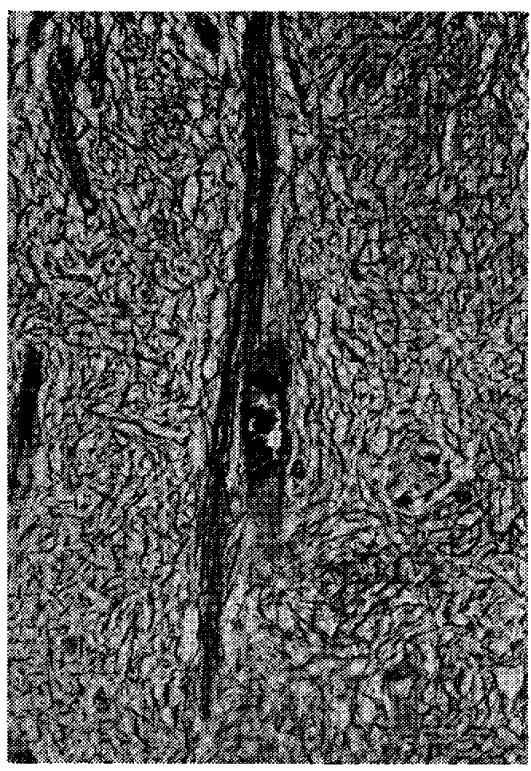

写 真 69

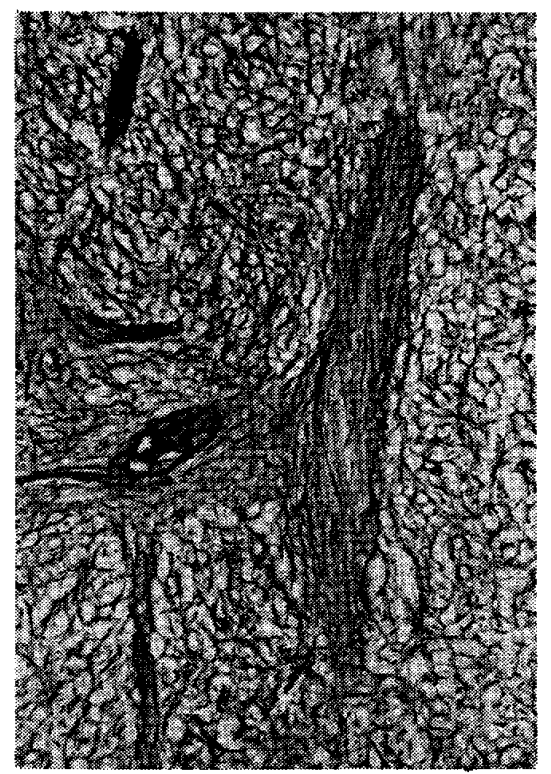

写 真 67

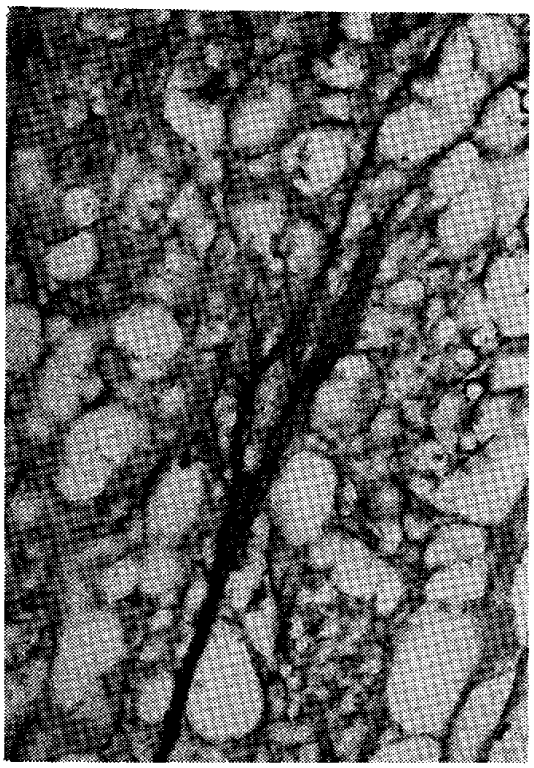

写 真 70

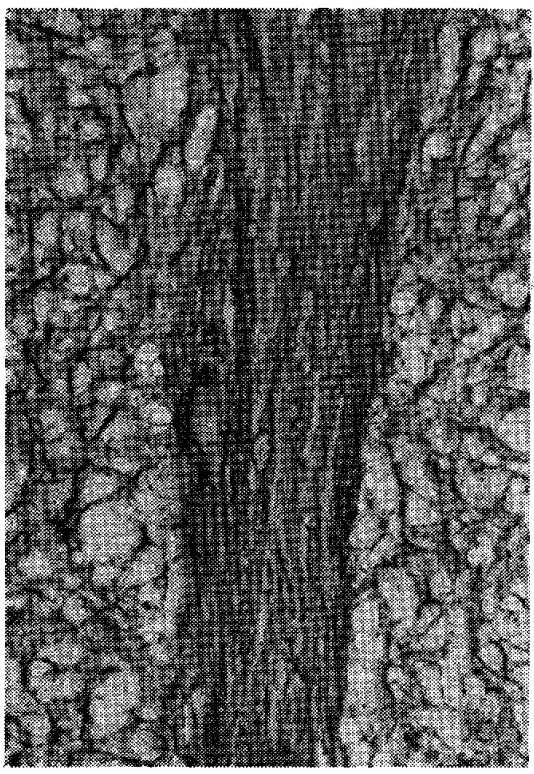

写 真 68

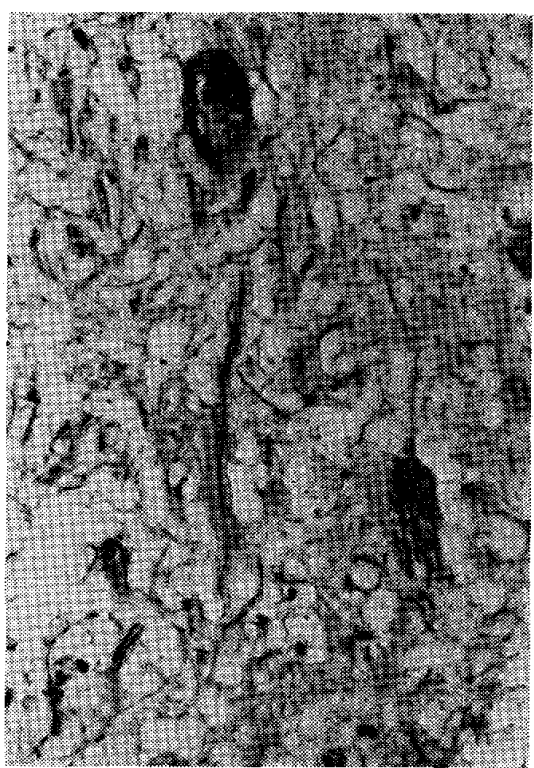

写 真 71
いては賛否両論があり，全く存在しないというもの，わ ずかに存在するもの，そして全体に認められるというも のまでその報告例は様々である．しかしながら，今回の 著者の観察結果は，匊䯋息肉内に神経が存在しないとい う意見を全く否定するものであった。

息肉内の神経線維の存在について，てのように意見が わかれた原因については，その一つに神経線維が存在し ないとする文献は比較的古いものに多くみられる。この ことは神経の染色技術によるものではなかららかと考元 られる. 岡部 $(1940)^{22}$ は息肉内の再生神経線維は好銀 性が固有菌髄内のものと比較して低下していると述べて
おらり，著者の観察結果でも息肉内の神経線維の染色性の 低下が認められたことはこれを裏づけるものではないか と思われる。

歯㫿息肉内における神経線維の走行について岡部 (1940）2 2) は根部茵䪔においては正常なものと大差はな い所見を示したが，分布量は低下していた．そしててれ らの神経線維は, 束を形成して上舁し, 歯嗔息肉との境 界部で左右に分岐し，さらに上方に向って走行する。そ して上方に向うに従い，数およびその径を減し，走行も 不規則となり，上層部に達すると述べている。

著者の観察結果でも残存雬髄内より白血球首近くの幼 
若肉芽組織層に至るまでの神経線維は菌軸とほぼ平行に 上昇するが，なかには蛇行あるいは波状に走行する神経 線維も諗められた。 そして幼若肉芽組織粕加ら白血球層 にかけてはその走行が不規則であった．ての事実は先に 述べた Martinelli ら $(1970)^{25}$ おうよび岡部 $(1940)^{221}$ の報告とほぼ同様のものであった，しかしながら，歯 髄息肉内の神経線維は変性を受けていなかったとする Martinelli ら $(1970)^{25)}$ の報告屽著者の観察結果から肯 定することはできなかったすすなわち，著者の観察結果 では幼若肉芽組織首から結合織層および残存菌髄組織内 にかけては変性した神経線維, 增殖する Schwann細胞 および Büngner 氏索を形成する神経線維等が混在して 認められたからである．また，乙の事実は岡部（1940） 221が述べるように息肉内の神経線維は周囲健康歯学道内 の神経線維より再生したものであるととを確証するもの であった。

慢性閉鎖性菌髄炎では膿瘍膜内に多数の微細な神経線 維の網状分布がみられ，乙れらはそのほとんどが健全な 神経線維であった。そして膿瘍周囲にはSchwann 細胞 の増殖を伴う神経束がみられたが，その他の健康歯䯣内 においては正常所見を呈した。

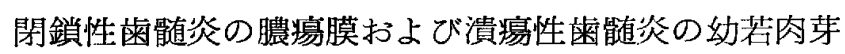
組織はいずれも細菌の刺激に対する防禦壁となるもので あるが，てれらの壁内にみられた健全なる細い神経線維 の網状分布所見は甚で特異的で興味ある所見である.

\section{4) 退行性病変}

空胞変性に陷った菌髄内では，象牙芽細胞層内に進入 する神経線維には軽度の変性が認められる程度で, 全体 として藷変は認められなかった．また, 象牙芽細胞首直 下の Raschkow の神経叢についても著変は認められな かった.

石灰変性では神経線維はほとんどのものが膨化，断裂 および顆粒状崩壊などをおてし，なかには消失寸前のも のも認められ，健全な神経線維はほとんど認められなか った。

網様萎縮に陥ったものでは，神経線維は萎縮が軽度な ものでは，萎縮に陷った部立抽よびその周囲を走行する 神経線維は膨化あるいは染色性の低下などの変性所見を 呈する神経線維と健全な神経線維とが混在して誌められ た。しかしながら，萎縮が菌葡全体に拡がった症例で は, 神経線維は全て空胞形成, 顆粒状崩壊などの変性を おてし，消失または消失寸前の所見を呈し，健全な神経 線維は全く悲められなかった。

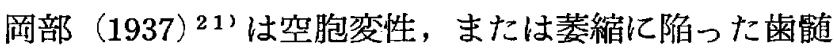

内の神経線維における髄鞘の変化は, 空胞変性, または 萎縮の程度とは関係なく, 正常に近いものもあれば, 変 性が著しいものまで認められると述へているが, 著者の 観察結果からは岡部（1937） ${ }^{21}$ の報告之は全く異なるも のであり, 空胞変性に関しては神経線維の受ける損害は 極めて軽度であるてとを示した。

石灰変性と歯䯣内神経に関する報告は極めて少なく，

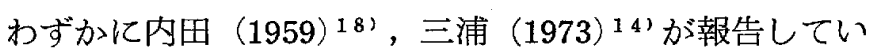
るだけである．内田（1959） $\left.{ }^{18}\right)$ は石灰変性は硝子様変性 を伴うことが多く，乙れを伴うものでは石灰化部周囲の 神経線維は鹃遖䩗が消失している所見を示すが，硝子椂変 性を伴わないものでは髄鞘が存在していると述べてい る. 三浦 $(1973)^{14}$ もまた石灭変性は硝子椂変性を伴。 て出現することが多く，てれらの場合，他の退行性病変 に比へ最も神経線維の受ける変性は高度であると報告し ている。

著者の観察結果でも硝子様変性を伴った症例が 3 例に みられ，これらは三浦（1973）14' の報告を確証するもの であった。

内田 (1959) ${ }^{18)}$ は網様萎縮に陥った茵髄内神経線維は 萎縮が軽度なものでは変性は冠部菌髄に主として観察さ れ，特に紐い神経線維または神経束には正常なものは諗 めなかったが，太いものでは軽度であったと述へ，また 菱縮が 高度なものでは歯髄周辺の細い神経線維は消失 し，中央部でも変性は著明に認められ，崩壊あるいは消 失した所見もみられたと報告している。乙れと逆に三浦 (1973) ${ }^{14)}$ は菱縮が軽度なものでは径の太い神経線維に 断裂, 空胞形成などの変性が生じ, 萎縮が高度になると 太い神経線維は断裂，顆粒化，そして消失寸前の所見を 呈するようになるが，微細な神経線維は変性に陥った所 見を呈するが，未だ存在すると述べている。

著者の観察結果では萎縮の程度と神経線維の変性との 相関性では一致したが, 細い神経線維が強い変性をおこ すと述べる内田 $(1959)^{18}$ ） の報告とは全く逆の結果で，

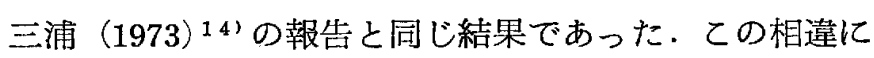
ついは三浦 $(1973)^{14}$ 之著者が同じ軸索染色法を用い たのに対し内田 $(1959)^{18)}$ は蹃鞘染色法を用いており， その結果, 植物神経等の細い無置神経が染色されなかつ たととも一つの原因ではなからうかと考える。

\section{結 論}

著者は歯髄疾患時における歯䯣内神経線維の動態を検 荣するためにヒトの抜去歯牙227本を用いて，連続切片 標本を作製し，神経染色法を施し観察し，次のような結 
論を得た。

1. 粜髄充血の場合, 初期のものでは神経線維に著変 はみられないが，充血が永続するものでは，軽度の膨 化, 染色性の低下, 念珠状変化などの 所見が認められ た。

2 、急性漿液性歯髄炎の場合, 炎症巣および周囲を走 行する神経線維には膨化, 染色性の低下および蛇行の所 見が認められたが，てれらの変化をおこした神経線維は 径の大きいものがほとんどで, 細い神経線維はその大多 数が健全な所見を呈していた。

3. 急性化膿性歯髄炎では炎症が一部に限局している 場合，限局性化膿巣古囲む炎症性組織内にみられる神経 線維の多くは変性に陌っているが, 細い神経線維には健 全なものが認められた。しかしながら，化膿性炎症が菌 䯣全体におよぶものではほとんどの神経線維に変性所見 を認めた。

4. 急性壊疽性歯髄炎の場合, 全ての神経線維に著し い変性あるいは崩壊過程が諗められた。

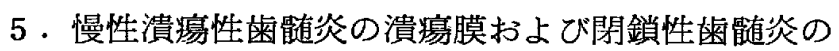
膿汮膜内に特異的に微細な神経線維の 網状分布を認め た。
6. 歯髄息肉内には再生神経線維が相当数存在し, 最 表層の白血球篃内に自由終末を送っているのも認められ た.

7. 空胞変性に陷った象牙芽細胞層に分布している神 経線維には著変は認められなかった。

8. 石灰変性に陥った神経線維は，そのほとんどのも のが，膨化，断裂および顆粒状崩壊をおこし，なかには 消失寸前のものも数多く認められた.

9.網様萎縮では萎縮初期のものではほとんど変化は ないが萎縮の進行とともに神経線維の変性も進み, 広く 䨑餚全体に萎縮がみられる症例では, 神経線維はそのほ とんどに著明な変性所見を認めた。

10. 以上の所見から歯髄内神経線維は各種䨑髄疾患時 に扔ける破壊性変化に対して抵抗力が強く, 周囲組織よ りもかなり生存期間が長いようである。

謝辞

稿を終るに臨み，終始御愁篤なる御指導を賜わった上 野正康教授に深甚なる感謝の意を表します.また本研究 に御援助, 御協力を戴きました教室員の皆椂に心から御 礼を申し上げます。

\section{引用 文 献}

1) Wassermann, F.: The innervation of teeth. J. Am. Dent. Assoc. $26: 1097-1109,1939$.

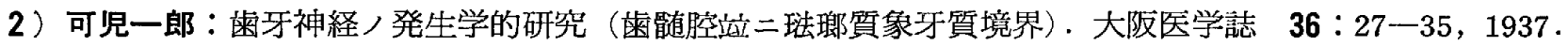

3）寺坂卯吉：人類雨牙特に象牙質内神経線維に関する研究補遺 (其三). 粜科学報 $44: 1 \sim 16,1939$.

4) Bernick, S. : Innervation of the human tooth. Anat. Rec. 101:81-107, 1948.

5 ) Powers, M.M. : The staining of nerve fibers in teeth. J. Dent. Res. 31:383-392, 1952.

6 ) Philipp, J. J. : Extent of distribution of nerve fibers in the human tooth. J. Am. Dent. Assoc. $50: 22-34,1955$.

7 ）高木正邦・東 義景・織田正豊：畨䯋の神経分布について〔会]．菌基礎誌 $15 ： 264 ， 1973$.

8 ) Itoh, K. : The distribution of nerves in human deciduous and permanent teeth. Arch. Histol. Jap. 39:379-399, 1976.

9）伊東且裕・土屋 博・脇田 稔・小林茂夫：カニクイザル米牙系の 神経分布について〔会】. 解剖誌 53 ： $470-471,1978$.

10）北村勝也・伊高三千男・別府正敏：各種動物の口腔組織神経分布に関する研究.（そのII）犬，猫の菌牙内 神経について. 九州歯会誌 $12: 171-176,1958$.

11）上野正康・北村勝也・伊高三千男・別府正敏：各種動物の口腔組織神経分布に関する研究.（そのII）家兔, モルモット，白鼠，二十日鼠の歯牙内神経について，九州歯会誌 $12: 362-368 ， 1958$.

12）上野正康・北村勝也・松永隆義・永田 萃・佐田 榃：各種動物の口腔組織神経分布に関する研究.（其の IV) 犬，猫，家鬼，モルモット，白鼠，二十日鼠の歯根膜に於ける神経分布．九州菌会誌 $13: 880-$ 887,1960 .

13）上野正康：尿素一硝酸銀染色法による雬髄内神経知見補遺. 歯基礎誌 $3: 86-88,1961$. 
14）三浦哲夫：ヒト蒾牙内神経線維の加令的変化に関する研究. 九州歯会誌 $26: 278-298,1973$.

15) Graf, W. and Björlin, G.: Diameters of nerve fibers in human tooth pulps. J. Am. Dent. Assoc. 43 : 186-193, 1951.

16）本間藤彦：下蒾槽神経とその分枝の線維構成について〔会〕. 解剖誌 $32: 46-47,1957$.

17）内薗耕二・本間邦則：歯の神経の電子顕微鏡的研究.（第 1 報）曾界展望 $15: 1403-1407,1958$.

18）内田 仙：歯髄の有髄神経線維，とくに葡鞘に関する病理組織学的研究. 口病誌 $26: 721-737,1959$.

19）三好作一郎：人の曾髄の電子顕微鏡的観察. 阪大歯学誌 $11: 131-154,1966$.

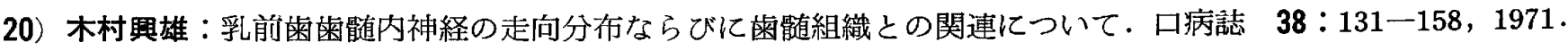

21）岡部圭司：人類柬髄神経䯣鞘成分ノ病理組織学的変化 [会]. 口病誌 $11: 369-370,1937$.

22) 岡部圭司：曾髄息肉ノ神経分布二関スル形態学的研究. 口病誌 $14: 141-148,1940$.

23) Plačková, A. : Pathologic changes in the innervation of the dental pulp during the carious process. J. Dent. Res. $45: 62-65,1966$.

24) Mullaney, T. P., Howell, R. M. and Petrich, J. D. : Resistance of nerve fibers to pulpal necrosis.Oral Surg. 30:690-693, 1970 .

25) Martinelli, C. and Toledo, O. A. : The innervation of human pulp polyps. Bull. Tokyo Dent. Coll. $11: 11-18,1970$.

26) Bernick, S. : Vascular and nerve changes associated with the healing of the human pulp. Oral Surg. $33: 983-1000,1972$.

27) Almeida, O. P. and Bozzo, L. : Morphology of the nerve fibers in both normal and inflamed human dental pulp. Acta Anat. $84: 597-607,1973$.

28) Torneck, C. D. : Changes in the fine structure of the dental pulp in human caries pulpitis. 1. Nerves and blood vessels. J. Oral Pathol. 3:71-82, 1974 .

29) England, M. C., Pellis, E. G. and Michanowicz, A.E. : Histopathologic study of the effect of pulpal disease upon nerve fibers of the human dental pulp. Oral Surg. 38:783-790, 1974 .

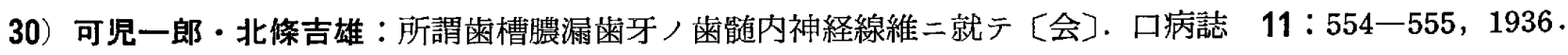

31）本間藤彦：雬槽膿漏における歯髄内有髄神経について〔会〕みちのく函学誌 $2: 16,1971$.

32) 中村平雄 : 雬牙, 死後変化二関スル 実験的研究. 第 4 篇. 雬髄内神経線維, 死後変化二就イテ. 口病誌 $14: 214-222,1940$.

33) Blair, G. H. and Wyke, B.D. (1963) : 28) Torneck より引用.

34) Rapp, R., Avery, J. K. and Strachan, D. S. : The distribution of nerves in human primary teeth. Anat. Rec. $159: 89-104,1967$.

35) Cajal, S.R. : Degeneration of interrupted nerves. In : Degeneration and regeneration of nervous system (ed. by May, R. M.). Hafnar Publishing Co., New York, 1959, 66-166.

36) Young, J.Z. : The functional repair of nervous tissue. Physiol. Rev. $22: 318-374,1942$.

37）迫田隅男：舌の創傷治癒に関する神経組織学的研究. 九州宷会誌 $30: 401-422,1976$.

38）渡辺龍一・佐藤敏夫・伊藤 司：末梢神経線維の呺逍鞘変性に関する実験的研究. 福島医誌 6:131一149, 1956.

39）安藤慎一郎：歯肉切除創の治瘾経過にともなう神経線維分布の消長に関する研究. 九州菌会誌 $34: 377 一$ 397,1980 .

40) Dixon, A.D. and Peach, R. : Fine structure of epithelial and connective tissue elements in human dental polyps. Arch. Oral Biol. $10: 71-81,1965$.

41) Pucci, F. M. and Reig, R. (1944)：25) Martinelli らより引用.

42) Römer, O. (1909)：22）岡部より弓用.

43）Varella, J. A. F. and Paiva, J. G.（1963）：25）Martinelli らより引用. 